\title{
AS DIMENSÕES DEMOCRATIZANTES DO CPC / 2015 E SEUS IMPACTOS NA CULTURA JURÍDICA PROCESSUAL ESTABELECIDA ${ }^{1}$
}

\author{
THE DEMOCRATIZING DIMENSIONS OF CPC / 2015 AND ITS IMPACTS ON \\ THE ESTABLISHED PROCEDURAL LEGAL CULTURE
}

\section{LAS DIMENSIONES DEMOCRATIZANTES DEL CPC / 2015 Y SUS IMPACTOS EN LA CULTURA JURÍDICA PROCESAL ESTABLECIDA}

\author{
AleXANDRe de CAstro Catharina \\ https://orcid.org/0000-0003-3999-229X / http://lattes.cnpq.br/4302536084183986 / alexandre.catharina@hotmail.com.br \\ Universidade Estácio de Sá, UNESA. \\ Rio de Janeiro, RJ, Brasil.
}

\begin{abstract}
RESUMO
O Código de Processo Civil de 2015 trouxe importantes inovações normativas, principalmente no que diz respeito à democratização da organização do procedimento, através da instituição do negócio processual, por exemplo, e da construção democrática do processo decisório, mediante a expansão da atuação do amicus curiae no processo civil. Esse modelo participativo e democrático de processo, embora necessário no Estado Democrático de Direito, não decorre da cultura jurídica processual brasileira, fortemente influenciada pelo modelo processual liberal de matriz europeia. E é exatamente neste sentido que se faz necessário investigar, sobretudo após os primeiros anos de vigência do Código de Processo Civil, os impactos que estes institutos causaram em nossa cultura jurídica com o escopo de identificar se os objetivos pretendidos foram alcançados ou compreender os obstáculos, institucionais ou pragmáticos, que inviabilizaram sua eficácia. Com efeito, pretende-se, nos três capítulos que estruturam o artigo, analisar, a partir da dinâmica institucional do Poder Judiciário, quais institutos de participação e democratização foram efetivamente aplicados em nossa prática forense para, a partir dos dados, refletir sobre a cultura jurídica processual brasileira e suas tensões com o conteúdo normativo do Código de Processo Civil de 2015. Para tanto, utiliza-se no trabalho o método qualitativo-documental e quantitativo para coleta de dados e o método indutivo de investigação para refletir acerca dos dados coletados.
\end{abstract}

Palavras-chave: Cultura Jurídica Processual. Processo Civil. Processo Civil Democrático.

\begin{abstract}
The Code of Civil Procedure of 2015 brought important innovations, mainly in what concerns to the democratization of the organization of procedure, through the institution of procedural business, for example, and of democratic construction of the decision-making process, through the expansion of the amicus curiae civil lawsuit. This participatory and democratic model of process doesn't come from the Brazilian legal process culture, strongly influenced by the liberal process model of European nuance. And it's precisely in this sense that it's necessary to investigate, especially after the first years of the Civil Procedure Code, the impacts that these institutes have caused in our legal culture to identify whether the intended objectives were achieved or to understand the obstacles, institutional or pragmatic, that made its effectiveness unattainable. In fact, it is intended to analyze, from the institutional dynamics of the Judiciary, what institutes of participation and democratization were effectively applied in our forensic practice to, based on data, reflect on the Brazilian legal procedural culture and its tensions with the content Code of Civil Procedure of 2015. For that, it's used the qualitative-documentary and quantitative method to analyze the data collected.
\end{abstract}

Keywords: Legal Process Culture. Civil Procedure. Democratic Civil Procedure.

1 Este trabalho aborda os resultados das pesquisas realizadas em 2017, através do Programa de Bolsas Pesquisa Produtividade da Universidade Estácio de Sá, no Rio de Janeiro. Os dados foram coletados com auxílio dos pesquisadores do Observatório de Cultura jurídica processual e democratização do processo civil, Campus Nova América, UNESA, RJ. 


\section{RESUMEN}

El Código de Proceso Civil de 2015 trae importantes innovaciones, principalmente en lo que se refiere a la democratización de la organización del procedimiento, a través de la institución del negocio procesal, por ejemplo, y de la construcción democrática del proceso decisorio, mediante la expansión de la actuación del amicus curiae en el proceso civil. Este modelo participativo y democrático de proceso no deriva de la cultura jurídica procesal brasileña, fuertemente influenciada por el modelo procesal liberal de matiz europea. Y es precisamente en este sentido que se hace necesario investigar, sobre todo después de los primeros años de vigencia del Código de Proceso Civil, los impactos que estos institutos causaron en nuestra cultura jurídica con el objetivo de identificar si los objetivos pretendidos fueron alcanzados o comprender los obstáculos, institucionales o pragmáticos, que inviabilizaron su eficacia. En efecto, se pretende, pues, analizar, a partir de la dinámica institucional del Poder Judicial, cuáles institutos de participación y democratización se aplicaron efectivamente en nuestra práctica forense para, a partir de los datos, reflexionar sobre la cultura jurídica procesal brasileña y sus tensiones con el contenido normativo del Código de Proceso Civil de 2015. Para ello, utilizase en el trabajo el método cualitativo-documental y cuantitativo para analizar los datos recolectados.

Palabras clave: Cultura Jurídica Procesal. Proceso Civil. Proceso Civil Democrático.

\section{SUMÁRIO}

INTRODUÇAO; 1 DIMENSÕES DEMOCRATIZANTES DO CÓDIGO DE PROCESSO CIVIL DE 2015 E A CULTURA JURÍDICA PROCESSUAL BRASILEIRA; 2 CULTURA JURÍDICA E PRÁXIS FORENSE; 3 A TENSÃO ENTRE CULTURA JURÍDICA ESTABELECIDA E A DEMOCRATIZAÇÃO DO PROCESSO PROPOSTA NO CPC; CONCLUSÃO; REFERÊNCIAS.

\section{INTRODUÇÃO}

O Código de Processo Civil (CPC) de 2015 inovou ao dar tratamento normativo à diversas formas de participação dos sujeitos processuais na formulação de determinadas etapas do procedimento comum, como também avançou ao ampliar a atuação dos amici curiae, em todas as instâncias, nos processos com forte repercussão social. Esse viés participativo adotado pelo código conformou um importante desenho democrático na processualística brasileira.

Esse modelo democratizante de processo arquitetado pelo CPC/2015 não encontra precedentes na processualística brasileira, ainda fortemente marcada por um modelo processual assentado no protagonismo do julgador e no papel secundário atribuído às partes. Embora haja na literatura especializada autores como Dierle Nunes ${ }^{2}$, que apontaram para a necessidade de se consolidar um modelo democrático de processo $^{3}$, constata-se que, na vigência do CPC/1973, prevaleceu a concepção liberal de participação e contraditório na relação processual.

2 NUNES, Dierle. Processo jurisdicional democrático: uma análise crítica das reformas processuais. Curitiba: Juruá, 2012.

3 A reflexão sobre processo democrático na vigência do $\mathrm{CPC} / 73$ foi fundamental como contraponto ao modelo liberal europeu que se consolidou no Brasil. A obra de Dierle Nunes foi pioneira neste sentido. 
A transição normativa para um modelo democratizante de processo teve, portanto, início com o incremento de técnicas de padronização decisória, onde a força persuasiva da jurisprudência teve maior aplicação no Poder Judiciário brasileiro, através de dispositivos legais que atribuíam poderes ao relator para proferir decisões monocráticas (art. 557, CPC/73), observando a jurisprudência dominante de determinado tribunal ou mesmo enunciado de súmulas de tribunais superiores (art. 518, CPC/73).

É bem verdade que as reformas processuais ocorridas na vigência do Código de Processo Civil de 1973 tiveram como principal escopo assegurar maior racionalidade à atividade judicial, reduzindo o excesso de trabalho decorrente de ações repetitivas tanto nos tribunais locais como nas Cortes supremas. Pode-se afirmar, a partir dessa inferência, que a dinâmica dos precedentes judiciais foi transplantada para o ordenamento jurídico processual com a finalidade precípua de padronizar as decisões dos tribunais e dinamizar a atividade judicial com escopo na administração da justiça e descongestionamento do Judiciário. A isonomia e a segurança jurídica não eram, num primeiro momento, os principais vetores da reforma.

Foi exatamente nesse ambiente cultural e institucional que se desenvolveu o projeto de inserção gradual e contínua da dinâmica dos precedentes judiciais na processualística, ainda que de forma assistemática. Não há, em um primeiro momento, como sustentar que se pretendeu democratizar o procedimento comum ou mesmo o processo de formação da decisão judicial. Pretendeu-se estabelecer uma padronização decisória, apenas.

Entretanto, a vinculação crescente ${ }^{4}$ aos julgados das Cortes superiores exigiu do julgador maior consistência, tanto na fundamentação como na justificação das decisões paradigmas, de modo a dar maior força normativa e legitimidade à própria atuação legiferante das Cortes. $\mathrm{Na}$ jurisdição constitucional, a ampliação da atuação da sociedade civil nas ações constitucionais, com maior envergadura social e moral, foi decisiva para estimular a admissão dos amici curiae em diversos jugados do Supremo Tribunal Federal. ${ }^{5}$

O Código de Processo Civil de 2015, nesse contexto, foi desenhado originariamente para fortalecer o sistema de precedentes judiciais, com a declarada finalidade de dar maior previsibilidade às decisões judiciais e, como consequência, a desejada segurança jurídica através da vinculação dos tribunais locais aos precedentes das Cortes superiores. No entanto, a

Entretanto, na vigência do CPC/2015 se faz necessário repensar o processo civil democrático a partir de outras premissas teóricas e normativas. É o que se pretende com o presente estudo.

${ }^{4}$ Edição de súmulas vinculantes, julgamento de recursos extraordinários através de repercussão geral e julgamentos por amostragem através de recurso especial repetitivo.

${ }^{5}$ CATHARINA, Alexandre de Castro. Movimentos sociais e a construção dos precedentes judiciais. Juruá: Curitiba, 2015. 
legitimidade mesma dos precedentes judiciais, enquanto fonte normativa do direito, decorre da ampla participação e do intenso contraditório, pelo menos do ponto de vista normativo, na formação das decisões judiciais. Foi nessa toada que, a título de exemplificação, se estendeu a atuação dos amici curiae a partir do primeiro grau de jurisdição e a possibilidade de tese jurídica fixada em IRDR ser revista pela Defensoria Pública.

Essa nova arquitetura normativa traz em seu bojo as bases para consolidação de um processo civil democrático. Há dispositivos legais no Código de Processo Civil de 2015 que evidenciam essa proposta democratizante do código. Entretanto, cabe investigar se essa proposta vanguardista encontra amparo na cultura jurídica processual estabelecida na prática forense brasileira.

Não se pretende investigar as dimensões democratizantes do processo civil exclusivamente do ponto normativo. É necessário ir além. Pretende-se, portanto, analisar os impactos que a proposta normativa do Código de Processo Civil de 2015 teve na cultura jurídica e na práxis forense do Poder Judiciário brasileiro. Para tanto, analisa-se como vem sendo aplicado os dispositivos jurídicos que tratam da democratização do processo decisório e em que medida essas inovações processuais, de fato, impactaram na cultura jurídica.

Importante ressaltar que o conceito de democratização utilizado no trabalho não se limita ao contraditório amplo realizado entre autor e réu em determinado processo judicial. Democratização, para os fins desse artigo, corresponde à participação de outros sujeitos que não integram a relação processual, mas são autorizados a influir do processo decisório, como ocorre na atuação de atores sociais no julgamento do Incidente de Resolução de Demandas Repetitivas (IRDR), entre outros procedimentos.

Assim, aborda-se, num primeiro momento, as dimensões democratizantes do Código de Processo Civil de 2015, acentuadas em diversos dispositivos legais, e as características fundantes da cultura jurídica processual brasileira. Num segundo momento, ocupa-se da práxis judiciária brasileira, a partir da análise dos dados empíricos coletados, com destaque para a participação dos amigos da corte no julgamento dos IRDRs e nas audiências públicas que foram realizadas na vigência do Código de Processo Civil de 2015. Por fim, pretende-se fazer um contraponto entre as dimensões democratizantes do código e a práxis forense brasileira, destacando eventuais tensões entre a democratização do processo judicial, concebida normativamente pelo CPC, e seus impactos na cultura jurídica processual estabelecida.

A metodologia de pesquisa utilizada no trabalho articula os aportes dos métodos quantitativo e qualitativo para se alcançar os resultados pretendidos. 0 método quantitativo foi 
aplicado na coleta e tabulação dos dados estatísticos levantados no Conselho Nacional de Justiça e nos sítios dos Tribunais de Justiça dos estados do Rio de Janeiro, São Paulo, Minas Gerais, Rio Grande do Sul, Goiás e Bahia. A utilização do método qualitativo teve como recorte a análise das decisões judiciais que admitiram o ingresso dos amigos da Corte, de modo a verificar quem são e quais os argumentos utilizados por estes para participar do processo decisório. Por outro lado, esse método permite, também, identificar, nos argumentos dos amigos da Corte, qual a principal motivação para atuação no âmbito do Poder Judiciário. Os dados coletados serão analisados a partir do método indutivo de investigação.

\section{DIMENSÕES DEMOCRATIZANTES DO CÓDIGO DE PROCESSO CIVIL DE 2015 E A CULTURA JURÍDICA PROCESSUAL BRASILEIRA}

O Código de Processo Civil de 2015 trouxe em seu bojo diversos dispositivos legais que possibilitam a democratização do procedimento e do processo decisório. Denomina-se de dimensões democratizantes do processo civil esse conjunto de regras ${ }^{6}$. Necessária, então, a análise detalhada destes dispositivos legais.

A primeira dimensão concerne à inovação normativa referente à legitimação para agir. A legitimação ativa e passiva das associações irregulares e outros entes organizados sem personalidade jurídica (artigo 75, IX, do Código de Processo Civil) contempla, sem dúvidas, a possibilidade dos movimentos sociais e entidades da sociedade civil ajuizarem demandas para tutela de seus interesses sociais, políticos e jurídicos. Trata-se de regra sem precedentes na processualística brasileira, pois ao longo do desenvolvimento científico do processo civil considerava-se como sujeitos processuais somente indivíduos ou pessoas jurídicas de direito público ou privado.

A regra decorre, em certo sentido, da expansão da judicialização das relações sociais e políticas, apontada por Werneck Vianna ${ }^{7}$ na década de 1990, para os tribunais locais através de ações judiciais que retratavam conflitos sociais pela terra, por habitação ou mesmo por serviços públicos, como atendimento médico ou educação básica. Os conflitos sociais coletivos eram

\footnotetext{
${ }^{6}$ A proposta participativa e democratizante do código pode, também, ser pensada a partir da teoria democrática e procedimentalista de Habermas, onde o próprio direito (processual), através da participação da sociedade, atua como um médium entre os sistemas econômico e político e suas relações com o mundo da vida. HABERMAS, Jurguen. Direito e Democracia: entre a facticidade e validade. 2. Ed. Rio de Janeiro: Tempo Brasileiro, 2003.

7 WERNECK, Luiz Vianna et all, A judicialização da política e das relações sociais no Brasil. Rio de Janeiro: Revan, 1999.
} 
judicializados, inicialmente, pelo Ministério Público, como resultado de sua legitimação constitucional (artigo 127 da Constituição Federal de 1988) e, posteriormente, parte dessa demanda vinha sendo judicializada pela Defensoria Pública ${ }^{8}$.

Entretanto, boa parte das demandas das coletividades eram excluídas em razão da limitação estrutural e do volume de ações judiciais que, ainda na contemporaneidade, são encaminhadas para essas instituições. Atribuir legitimidade às coletividades para que essas pleiteiem a tutela de seus interesses em juízo não só assegura maior representatividade adequada dos atores envolvidos nos conflitos como também permite maior associativismo. ${ }^{9}$

Nesse contexto, a partir da legitimidade conferida, os movimentos sociais e entidades da sociedade civil podem impugnar de forma adequada políticas públicas que contrariam os interesses da população local ou mesmo pressionar o Poder Público ou a iniciativa privada nos casos concernentes às questões ambientais, de gênero e raciais. Com efeito, legitimar os movimentos sociais e entidades da sociedade civil para ajuizamento de suas demandas em juízo é propiciar a construção da denominada cidadania social, conforme bem acentuou Werneck Vianna ${ }^{10}$, o que é fundamental para coletivização e democratização do processo civil, como também para consolidação de uma sociedade inclusiva.

Outra importante inovação foi o alargamento da atuação dos amici curiae (artigo 138 do (PC) no capítulo concernente à intervenção de terceiros. 0 amicus curiae foi inserido em nosso ordenamento jurídico, inicialmente, através da Lei $n^{\circ} 9.868 / 1999$, que dispõe sobre controle concentrado da constitucionalidade, e da Lei $\mathrm{n}^{\circ}$ 9.882/1999, que regula a ação de descumprimento fundamental. 0 artigo $6^{\circ}, \$ 1^{\circ}$, da Lei $n^{\circ} 9.882 / 1999$ dispõe que "se entender necessário, poderá o relator ouvir as partes nos processos que ensejaram a arguição, requisitar informações adicionais, designar perito ou comissão de peritos para que emita parecer sobre a questão, ou ainda, fixar data para declarações, em audiência pública, de pessoas com experiência e autoridade na matéria"11.

\footnotetext{
8 A legitimação da Defensoria Pública para defesa de direitos e interesses coletivos e difusos foi assegurada pela Lei ${ }^{\circ} 11.448 / 2007$, que deu nova redação ao art. $5^{\circ}$, II, da Lei $n^{\circ} 7.347 / 1985$.

9 WERNECK VIANNA, Luiz; BURGOS, Marcelo. Revolução processual do direito e democracia progressiva. In: WERNECK VIANNA, Luiz (Coord.). A democracia e os três Poderes no Brasil. Belo Horizonte: UFMG, 2002. 10 WERNECK VIANNA, Luiz; BURGOS, Marcelo. Revolução processual do direito e democracia progressiva. In: WERNECK VIANNA, Luiz (Coord.). A democracia e os três Poderes no Brasil. Belo Horizonte: UFMG, 2002.

11 BRASIL. Lei n9.882, de 03 de dezembro de 1999.Dispõe sobre o processo e julgamento da arguição de descumprimento de preceito fundamental, nos termos do $\$ 1^{\circ}$ do art. 102 da Constituição Federal. Diário Oficial da União. Brasília. DF. 06 dez. 1999. Disponível em:
} http://www.planalto.gov.br/ccivil_03/leis//9882.htm. Acesso em: 15 maio 2018. 
O $\$ 1^{\circ}$ do artigo $9^{\circ}$ da Lei $n^{\circ} 9.868 / 1999$ possui redação semelhante ao dispositivo mencionado acima ao dispor que:

[...] em caso de necessidade de esclarecimento de matéria ou circunstância de fato ou de notória insuficiência das informações existentes nos autos, poderá o relator requisitar informações adicionais, designar perito ou comissão de peritos para que emita parecer sobre a questão, ou fixar data para, em audiência pública, ouvir depoimentos de pessoas com experiência e autoridade na matéria. ${ }^{12}$

Como se verifica, o amicus curiae ingressou em nossa processualística como uma espécie de auxiliar externo ou um expert cuja principal função é fornecer informações adicionais, de modo a possibilitar ao relator o acesso a maiores esclarecimentos acerca do pedido a ser apreciado no processo objetivo. No entanto, a prática da jurisdição constitucional identificou o efeito colateral das regras acima, caracterizado pela ampla utilização do instituto pelos movimentos sociais e pela sociedade civil organizada no julgamento das ações constitucionais, conforme demonstrado por Alexandre Catharina. ${ }^{13}$

Outra interessante dimensão democratizante do Código de Processo Civil de 2015 concerne à regra do artigo 139, inciso X. Tal regra determina que o juiz deverá oficiar o Ministério Público e a Defensoria Pública, assim como os demais legitimados do artigo $5^{\circ}$ da Lei n 7.347/1985 (Lei da Ação Civil Pública), nos casos de demandas individuais repetitivas, para viabilizar, se for o caso, eventual distribuição da respectiva ação coletiva. Embora não se possa afirmar que a regra terá ampla aplicabilidade, considerando que será mais interessante para o Poder Judiciário, do ponto de vista da administração judiciária, instaurar Incidente de Resolução de Demandas Repetitivas, ressalta-se que a regra traz um importante diálogo social entre o Poder Judiciário e as instituições e as entidades legitimadas para a defesa dos interesses difusos e coletivos.

Em outra perspectiva, os conflitos coletivos pela terra e por habitação não foram desconsiderados pelo Código de Processo $\mathrm{Civil}^{14}$. $\mathrm{O}$ código dispõe sobre a necessária intimação do

\footnotetext{
12 BRASIL. Lei n 9.882 , de 03 de dezembro de 1999.Dispõe sobre o processo e julgamento da arguição de descumprimento de preceito fundamental, nos termos do $\$ 1^{\circ}$ do art. 102 da Constituição Federal. Diário Oficial da União. Brasília. DF. 06 dez. 1999. Disponível em: http://www.planalto.gov.br/ccivil_03/leis/19882.htm. Acesso em: 15 maio 2018.

${ }^{13}$ CATHARINA, Alexandre. Movimentos Sociais e a construção dos precedentes judiciais. Curitiba: Juruá, 2015.

14 BRASIL. Lei $\mathrm{n}^{\circ} 13.105$, de 16 de março de 2015. Código de Processo Civil. Diário Oficila da União. Brasília, DF, 17 mar 2015. Disponível em: http://www.planalto.gov.br/ccivil_03/_ato20152018/lei/l13105.htm. Acesso em: 15 maio 2018.
} 
Ministério Público e da Defensoria Pública ${ }^{15}$ nos conflitos coletivos pela posse de bens imóveis $\left(554, \S \S 1^{\circ}\right.$ e $\left.3^{\circ}\right)$, mas o principal avanço normativo na temática diz respeito à necessária designação de audiência de mediação quando a ocupação for superior a 01 ano (artigo 565). Não se admite decisões liminares ou qualquer outra decisão judicial sem antes viabilizar a mediação entre a coletividade e os proprietários dos imóveis. A regra é relevante pois os conflitos coletivos pela posse de bens imóveis possuem grande importância social e política no Brasil.

Em outra dimensão, o código pretendeu organizar um conjunto de regras sobre precedentes judiciais vinculantes ${ }^{16}$ com o objetivo de alcançar maior segurança jurídica e previsibilidade das decisões judiciais. É nesse contexto que o ordenamento jurídico faz a transição do civil law para um sistema híbrido onde tanto a lei quanto os precedentes judiciais possuem conteúdo normativo ${ }^{17}$. A questão que se coloca, nesse cenário, é como assegurar legitimidade aos precedentes judiciais, normativos e vinculantes, vez que os mesmos são editados pelas denominadas Cortes de Precedentes, como prefere setores da doutrina ${ }^{18}$, sem a participação popular.

Há dispositivos legais que autorizam, em alguma medida, a participação da sociedade civil na construção do processo decisório que ensejará o precedente judicial. 0 artigo 927, \$2 do $\mathrm{CPC}^{19}$, em certo sentido, avança ao permitir a pluralização do debate no julgamento dos recursos excepcionais, através do ingresso dos amici curiae (artigo 1.038, I), ou mesmo designação de audiência pública para ouvir interessados (artigo 1,038, II).

Em outro prisma, nos casos em que houver necessidade de se alterar a tese jurídica fixada em precedentes judiciais, o código faculta aos tribunais, previamente, designar audiência pública para ouvir pessoas, órgãos ou entidades que possam contribuir para rediscussão da tese (artigo 927, \$2). Nessa mesma linha de raciocínio, o artigo 983 autoriza o relator a ouvir pessoas, órgãos ou entidades interessadas na controvérsia debatida no Incidente de Resolução de Demandas Repetitivas.

15 O código atribuiu à Defensoria Pública a função de representar em juízo os movimentos sociais irregulares e coletividades sem representação, nos conflitos jurídicos em relação à terra e à propriedade imóvel, assegurando o pleno exercício da cidadania processual.

${ }^{16}$ Essa perspectiva teórica acerca dos precedentes judiciais pode ser identificada em MARINONI, Luiz Guilherme, Julgamento na Corte de precedentes, São Paulo: Revista dos Tribunais, 2017 e MITIDIERO, Daniel, Precedentes judiciais: da persuasão à vinculação. São Paulo: Revista dos Tribunais, 2017.

17 THEODORO JUNIOR, Humberto; NUNES, Dierle. BAHIA, Alexandre de Melo Franco; PEDRON, Flavio Quinaud. Novo CPC: Fundamentos e sistematização. 2 ed. Rio de Janeiro, Forense, 2015. p. 332.

${ }^{18}$ MARINONI, Luiz Guilherme. Julgamento nas cortes supremas: precedentes e decisão do recurso diante do novo CPC. São Paulo: Revista dos Tribunais, 2017.

19 BRASIL. Lei $\mathrm{n}^{\circ} 13.105$, de 16 de março de 2015. Código de Processo Civil. Diário Oficila da União. Brasília, DF, 17 mar 2015. Disponível em: http://www.planalto.gov.br/ccivil_03/_ato20152018/lei/l13105.htm. Acesso em: 15 maio 2018. 
Essa dimensão democratizante na formação ou alteração dos precedentes judiciais pode ser observada na legitimação para ajuizamento da Reclamação (artigo 990), para preservação da autoridade dos precedentes judiciais, ou mesmo para ajuizamento de ação rescisória (artigo 967, II), principalmente nos casos de violação de norma jurídica.

Por fim, a democratização do processo decisório também pode ser identificado no julgamento do Incidente de Declaração de Inconstitucionalidade. Conforme dispõe o artigo 950 $\S 3^{\circ}$, o relator poderá admitir o ingresso de órgãos e entidades, com representatividade adequada, quando a relevância da matéria exigir. 0 mesmo se verifica no julgamento do incidente de resolução de divergência, nos termos do artigo 942 do CPC.

Esses dispositivos, pensados de forma sistemática, compõe o que denominamos de dimensões democratizantes do Código de Processo Civil, cuja principal finalidade é assegurar a democratização do debate nos casos em que a decisão judicial tiver amplo espectro jurídico, social e político.

As dimensões democratizantes do CPC analisadas acima repercutem, também, na teoria geral do processo. Além de impactar na teoria do direito, sobretudo no que tange à revisitação do conceito de norma sob a ótica da vinculação aos precedentes judiciais, o código exige, também, uma reformulação do conceito de contraditório e ampla defesa. Nesse sentido, Marinoni ${ }^{20}$ destaca que o modelo adotado pelo código reformula o papel das cortes superiores, que passam a ter a função pública de definição de sentido do direito e de estimular o debate para o aprofundamento da deliberação sobre a solução de disputas interpretativas na formação do precedente, onde a atuação do amicus curiae é fundamental para a decisão paradigma.

A teoria geral do processo que se consolidou sob a égide do Código de Processo Civil de 1973 tinha como referência epistemológica um modelo de processo assentado na solução de conflitos individuais ${ }^{21}$. Nesse contexto, o próprio conceito de jurisdição foi consolidado a partir das contribuições de Chiovenda e Carnellutti, mas tendo como referência um processo instaurado por um autor em face de um réu. Nessa toada, o conceito de contraditório, ampla defesa e devido processo legal foram pensados e aprimorados de modo a assegurar aos sujeitos processuais (autor e réu) a participação na formação da decisão judicial ${ }^{22}$.

\footnotetext{
${ }^{20}$ MARINONI, Luiz Guilherme, Julgamento nas Cortes Supremas: precedentes e decisão do recurso diante do novo CPC. São Paulo: Revista dos Tribunais, 2017. p. 26.

${ }^{21}$ ZAVASCKI. Teori Albino. Processo coletivo: tutela de direitos coletivos e tutela coletiva de direitos. 3. ed. São Paulo: Revista dos Tribunais, 2008.

22 MARINONI, Luiz Guilherme. Teoria Geral do Processo. 3. ed. São Paulo: Revista dos Tribunais, 2008. p.265.
} 
Nos casos em que a decisão fosse afetar a esfera jurídica de pessoas que não integravam a relação processual, o código autorizava o ingresso destas através de uma das modalidades de intervenção de terceiros. Se faz importante destacar que mesmo o instituto da intervenção de terceiro tinha como lógica fundante a perspectiva individualizada do processo, cujo principal escopo era a identificação da titularidade do direito e seus reflexos na esfera jurídica de terceiros.

O modelo democratizante de processo disposto no CPC exige, para sua adequada compreensão e aplicação, a reformulação de conceitos basilares da teoria geral do processo, em especial a necessária releitura do princípio do contraditório. Não se pode mais pensar o princípio do contraditório como a participação dos sujeitos processuais na formação da decisão judicial. Com as diversas possibilidades de ingresso de interessados, como pessoas, movimentos sociais, sociedade civil e entidades, nos processos com forte repercussão social, como foi vista acima, o conceito de contraditório deve abranger, também, a dinâmica da participação de segmentos da sociedade que serão afetados pela decisão judicial ou mesmo pelo precedente judicial vinculativo.

Diante desse contexto, os próprios meios processuais de provocação da jurisdição, meios estes que serão denominados neste trabalho como instrumentos processuais de participação ${ }^{23}$, também foram reformulados no próprio código. Nessa perspectiva, a ação rescisória e a reclamação tiveram seus raios de ação ampliados para contemplar o seu manejo por pessoas ou entidades interessadas na revisão de determinado julgado ou a garantia da autoridade de determinado precedente judicial nos casos em que for desconsiderado pelos juízes de primeiro grau.

A petição de ingresso dos amici curiae é, nessa linha de reflexão, um importante instrumento processual de participação e assegura o ingresso de interessados, em qualquer instância, e no julgamento de importantes incidentes processuais, como o Incidente de Resolução de Demandas Repetitivas. Assim, concebe-se como instrumento processual de participação ou de democratização todo e qualquer meio processual utilizado pelas partes ou por terceiros para ingressar em processos judiciais com ampla repercussão social e jurídica.

Antes de aprofundar a análise acerca dos impactos das dimensões democratizantes do CPC na cultura jurídica processual brasileira, se faz necessário traçar um breve panorama acerca

${ }^{23}$ CATHARINA, Alexandre de Castro. Movimentos sociais e a construção dos precedentes judiciais. Curitiba: Juruá, 2015. 
da própria formação da cultura jurídica e como ela pode ser verificada, ou mesmo compreendida, na prática dos tribunais.

A cultura jurídica brasileira teve como principal influência, num primeiro momento, o direito português ${ }^{24}$. Os principais institutos jurídicos brasileiros foram elaborados sob os influxos do direito português, francês, italiano e alemão. Percebe-se a influência do direito francês ou alemão ${ }^{25}$ mesmo no ordenamento jurídico atual. Nesse contexto, pode-se afirmar que a cultura jurídica processual brasileira foi, também, influenciada pela cultura jurídica liberal estruturante da prática jurídica brasileira.

Essa influência liberal na cultura jurídica processual pode ser identificada no modelo de processo individualizante e no empoderamento do juiz. A análise histórico-institucional do Poder Judiciário de Andrei Koerner ${ }^{26}$ ajuda na compreensão de como essa cultura jurídica se consolidou no Brasil.

Ao estudar as transformações do pensamento jurídico e as tensões sociais ocorridas na cultura jurídica, Koerner ${ }^{27}$ destaca que a transição do regime autoritário para o regime democrático estampado no texto constitucional de 1988, fenômeno comum na América Latina, atribuiu ao Poder Judiciário a função de promover a justiça substantiva e a modificação de relações sociais desiguais. Entretanto, as reformas políticas neoliberais impediram que as inovações institucionais fossem implementadas. Com efeito, o novo ordenamento constitucional, para o autor, não foi acompanhado de políticas públicas voltadas para as transformações da estrutura social. Nesse contexto, a prática judicial permanece como mediadora entre Estado liberal e as tensões sociais. Essa relação foi fundamental para a consolidação da cultura jurídica estabelecida.

Nessa linha de análise, conclui Koerner que as relações sociais e políticas são determinantes na formulação e reformulação do pensamento jurídico. A compreensão de uma cultura jurídica passa, necessariamente, pela identificação das tensões sociais e políticas que a

${ }^{24}$ CATHARINA, Alexandre de Castro. Ensino jurídico e reflexões sobre o novo Código de Processo Civil. In: BASTOS, Aurélio Wander. Os cursos jurídicos no Brasil- 190 anos. Rio de Janeiro: IAB Nacional, 2017. p. 102.

250 direito civil foi influenciado pelo direito francês, mais notadamente o direito contratual. No âmbito do direito processual civil brasileiro o regramento do incidente de resolução de demandas repetitivas no CPC sofreu forte influência do direito processual alemão.

${ }^{26}$ KOERNER, Andrei. Decisão Judicial, Instituições e Estrutura Socioeconômica: Por uma Análise Política do Pensamento Jurídico Brasileiro. In: ___ (Org.) História da Justiça Penal no Brasil: Pesquisas e Análises. São Paulo: IBCCRIM, 2006. p. 259-281.

${ }^{27}$ KOERNER, Andrei. Decisão Judicial, Instituições e Estrutura Socioeconômica: Por uma Análise Política do Pensamento Jurídico Brasileiro. In: Análises. São Paulo: IBCCRIM, 2006. p. 259-281. 
influenciaram. No Brasil, as matrizes liberais e individualizantes, com ênfase na propriedade privada e na atividade comercial, forjaram a cultura jurídica e política desde o período da escravidão e retroalimentaram a cultura jurídica que ainda perpassa nossa prática judiciária.

Em outro trabalho ${ }^{28}$, Koerner reforça o argumento ao sustentar que há continuidades na organização judiciária brasileira (no período de 1841-1920) a despeito da mudança social e política decorrente da transição da sociedade imperial e escravista para uma sociedade republicana e fundada no trabalho livre. Segundo o autor, essa organização judiciária conservadora tinha grande importância para continuidade dos arranjos entre políticas federais e do próprio coronelismo e da organização social hierarquizada que the é inerente. As principais consequências dessa prática judiciária foram a exclusão da resolução dos conflitos entre proprietários e não proprietários pelo mecanismo judicial e a exclusão dos indivíduos pobres da efetiva tutela judicial à vida, à segurança e, principalmente, às garantias constitucionais.

Esse ethos judiciário pode ser identificado ainda hoje na prática judiciária e na cultura jurídica processual estabelecida no país $^{29}$, com forte matriz patrimonial e individualizante da atividade judicial. E é exatamente nesse contexto que o Código de Processo Civil de 2015, com sua matriz democratizante, é inserido na cultura jurídica.

\section{CULTURA JURÍDICA E PRAXIS FORENSE}

O Código de Processo Civil está em vigor desde 2016 e se faz necessário investigar quais os impactos dessa inovadora legislação processual na cultura jurídica processual. A pesquisa realizada coletou dados nos sítios dos tribunais escolhidos conforme critérios expostos a seguir, com o objetivo de mapear em quais deles as dimensões democratizantes do código estão sendo utilizados e como estão sendo tratadas pelo Poder Judiciário em sua dimensão prática. Antes de analisarmos a dinâmica da participação dos amigos da Corte no julgamento dos IRDRs, se faz necessário expor, de forma clara, as etapas e os métodos de pesquisa utilizados para coleta da amostra utilizada.

\footnotetext{
${ }^{28}$ KOERNER, Andrei. Judiciário e cidadania na constituição da República brasileira (1841-1920). 2. ed. Curitiba: Juruá, 2010, p. 27.

29 Wolkmer, entre outros autores, analisam as características do constitucionalismo latino-americano e destacam que a expansão da atuação dos movimentos sociais na jurisdição constitucional tem sido fundamental para efetivação de importantes direitos e garantias constitucionais. Esse fenômeno, denominado por Wolkmer de constitucionalismo emancipatório, tem sido fundamental para superar a cultura jurídica individualizante e excludente. Ver WOLKMER, Antonio Carlos; RONCHI, M. Processos constituintes Latino-Americanos e a presença dos movimentos sociais no Brasil e na Bolívia. Revista Culturas Jurídicas, Niterói, RJ, v. 3, n 6, p. 151-171, 2017.
} 
A primeira etapa da pesquisa teve como escopo levantar os dados referentes ao quantitativo de IRDRs instaurados no período de vigência do Código de Processo Civil de 2015. Nessa perspectiva, foram levantados os incidentes registrados no Conselho Nacional de Justiça no período de 2014 a 2018, mas a análise se limitou aos incidentes instaurados no período compreendido entre os anos de 2016 e 2018. A segunda etapa da pesquisa teve como foco levantar quais áreas do direito eram objetos dos incidentes instaurados. Esse recorte se fez necessário considerando que há temas que se repetem em maior grau e intensidade que outros.

A terceira etapa teve como propósito levantar o número de incidentes distribuídos por regiões do país. Com efeito, pretendeu-se selecionar uma amostra que contemplasse, em alguma medida, os estados onde o volume de demandas seriais é considerável, de um lado, e os estados com maior número de habitantes ou maior movimento judiciário, de outro. A partir desta premissa, a amostra contemplou os estados da Região Sudeste, como Rio de Janeiro, Minas Gerais e São Paulo; Região Nordeste, representado pelo Estado da Bahia; Região Sul, representado pelo Estado do Rio Grande do Sul, e, por fim, pela Região Centro-Oeste, representado pelo Estado de Goiás. Importante ressaltar que nem todos os Tribunais de Justiça possuem dados disponíveis, o que dificulta a construção de uma amostra mais abrangente.

A quarta e última etapa consistiu na análise das audiências públicas realizadas na vigência do Código de Processo Civil de 2015. O propósito dessa etapa, mais qualitativa, teve como intuito verificar em que medida o alongamento das hipóteses de realização das audiências públicas no código refletiu na prática judiciária. Apresentados os passos metodológicos utilizados na coleta da amostragem, passa-se, pois, à análise mais acurada do IRDR.

O Incidente de Resolução de Demandas Repetitivas foi recebido com certo cuidado pela comunidade jurídica, considerando que não há em nosso direito processual método de julgamento similar. Para um segmento da literatura especializada, o incidente viabilizará maior celeridade e isonomia no trato das ações repetitivas, evitando decisões singulares e contraditórias $^{30}$. Outro segmento da doutrina destaca o risco de se consolidar um modelo de padronização decisória no âmbito dos tribunais, o que pode comprometer o amplo acesso à justiça ${ }^{31}$. No entanto, os dados coletados no sítio do Conselho Nacional de Justiça (CNJ) sugerem que a utilização do incidente vem aumentando consideravelmente em nossa prática forense ao longo dos anos iniciais de vigência do código.

30 MENDES, Aluisio Gonçalves de Castro. Incidentes de Resolução de Demandas Repetitivas: sistematização, análise e interpretação do novo instituto processual. Rio de Janeiro: Forense, 2017, p. 22.

31 THEODORO JUNIOR, Humberto; NUNES, Dierle. BAHIA, Alexandre de Melo Franco; PEDRON, Flavio Quinaud. Novo CPC: Fundamentos e sistematização. Rio de Janeiro, Forense, 2015. 
Se analisar a progressão na utilização do incidente distribuído por ramos da justiça, percebe-se que a Justiça Estadual recebe um número expressivo em relação aos outros. No período de vigência do código até abril de 2018 foram distribuídos na Justiça Estadual 145 incidentes, na Justiça Federal 13 e na Justiça do Trabalho 27. O gráfico abaixo permite visualizar o desequilíbrio na distribuição dos incidentes.

\section{GRÁFICO 1 - Distribuição dos IRDR por ramo da justiça}

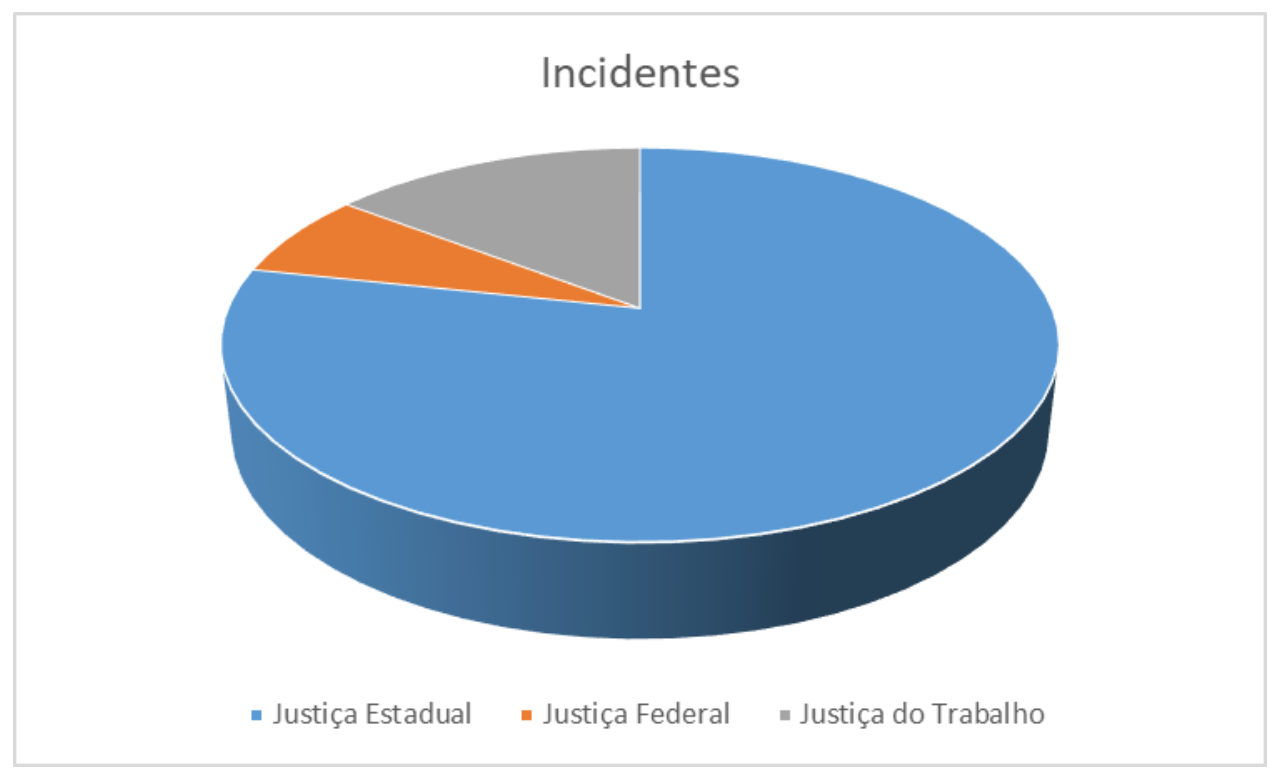

Fonte: Banco nacional de demandas repetitivas do Conselho Nacional de Justiça

Não há dúvida que a Justiça Estadual ${ }^{32}$ recebe grande volume de demandas repetitivas decorrentes de conflitos na relação de consumo e ações contra os Estados e Municípios, o que explica a busca por meios de padronização decisória no âmbito do tribunal. Exatamente por essa razão, parte considerável dos incidentes são suscitados pelos relatores dos recursos interpostos.

A análise quantitativa dos incidentes por ano de distribuição também revela que a cada ano, considerando o período posterior à vigência do código, aumenta de forma significativa na medida em que o procedimento vai sendo assimilado, como forma de racionalizar a atividade judicial pelo Poder Judiciário. Em 2014, foram distribuídos 02 incidentes. O CPC ainda não estava em vigor, o que sugere que o CNJ considerou outros meios de padronização, como

32 BRASIL. Conselho Nacional de Justiça. Banco Nacional de Demandas Repetitivas e Precedentes obrigatórios. 
aplicação de tese jurídica fixada em recursos repetitivos. Embora essa informação não conste nos dados disponibilizados pelo Conselho, pode ser inferir a partir do modelo de julgamento anterior ao código. Em 2015, foram registrados 04 incidentes, aplicando-se, portanto, a mesma análise de 2014.

Já em 2016, primeiro ano de vigência do código, foram distribuídos 62 incidentes. Esse dado é relevante pois conduz à constatação de que o incidente surgiu para atender uma demanda real e concreta do Poder Judiciário. Em 2017, o número de incidentes subiu para 102, tendo um aumento superior a 60\% em relação ao ano anterior. Em maio de 2018 já foram distribuídos 15 incidentes $^{33}$. Os dados sugerem a interpretação no sentido de que o Incidente de Resolução de Demandas Repetitivas possui intensa aplicabilidade na administração da justiça no Brasil.

\section{GRÁFICO 2 - Distribuição do IRDR por ano,}

Fonte: Banco nacional de demandas repetitivas do Conselho Nacional de Justiça

Se analisar os dados em outra perspectiva ${ }^{34}$, observando a distribuição dos incidentes por área do Direito, constata-se que o Direito Administrativo e outras possuem o maior número de incidentes distribuídos, seguido, com certa margem de distância, pelos casos relativos ao Direito Civil, Processual Civil e do Trabalho. Os casos sobre Direito Tributário, Consumidor, Direito do

\footnotetext{
${ }^{33}$ Os dados foram colhidos do site do CNJ cujo acesso foi realizado em: 07 maio 2018.

34 BRASIL. Conselho Nacional de Justiça. Banco Nacional de Demandas Repetitivas e Precedentes obrigatórios. Disponível em: https://paineis.cnj.jus.br/QvAJAXZfc/opendoc.htm?document=qvw_l\%2FPainelCNJ.qvw\&host=QVS\%40neo dimio03\&anonymous=true\&sheet=shDRGraficos. Acesso em: 16 maio 2018.
} 
Trabalho e Previdenciário estão em número menor. Já os casos que envolvem Direito Penal e Processo Penal possuem número reduzido de incidentes distribuídos, conforme se observa no gráfico abaixo.

\section{GRÁFICO 3 - Distribuição do IRDR por área do Direito}

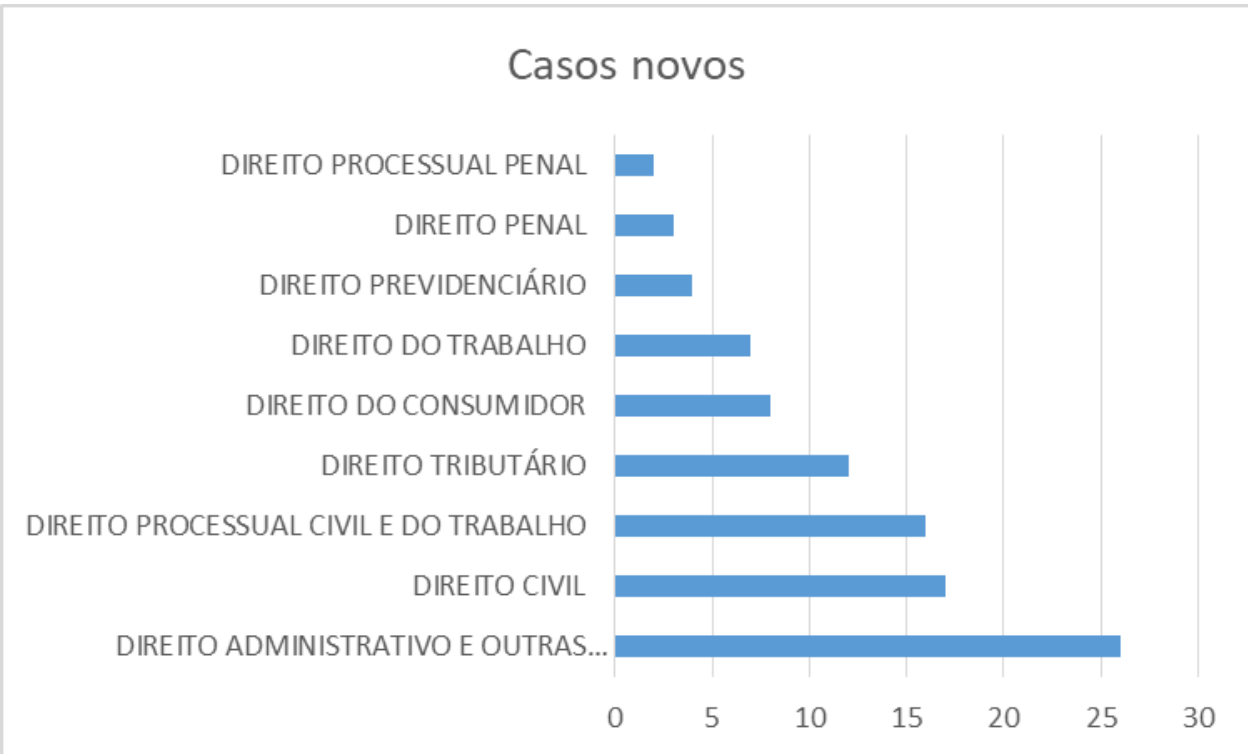

Fonte: Banco nacional de demandas repetitivas do Conselho Nacional de Justiça

A interpretação desses dados sugere que a maior parte dos incidentes são distribuídos e estão localizados na Justiça Estadual e envolvem, em sua maioria, temas relativos ao Direito Administrativo, principalmente em questões concernentes à Fazenda Pública, e ao Direito Civil. Exatamente os temas que congestionam a Justiça dos Estados ${ }^{35}$.

Os dados extraídos do sítio do CNJ somente permitem analisar a dimensão quantitativa do IRDR. No entanto, se faz necessário investigar a dimensão participativa ou democratizante do incidente no âmbito dos tribunais. Considerando que a maior parte dos incidentes foi distribuída na Justiça Estadual, a pesquisa coletou amostra de incidentes distribuídos nos principais Tribunais de Justiça dos Estados para analisar o grau e intensidade da participação dos interessados e terceiros no processo decisório do IRDR.

35 BRASIL. Conselho Nacional de Justiça. Banco Nacional de Demandas Repetitivas e Precedentes obrigatórios. dimio03\&anonymous=true\&sheet=shDRGraficos. Acesso em: 16 maio 2018. 
No Tribunal de Justiça do Estado do Rio de Janeiro ${ }^{36}$ foram distribuídos, entre 2016 e 2017, 14 incidentes. Em 2016, foram distribuídos 09 incidentes e, em 2017, 05 incidentes. A análise dos dados desse tribunal conduzem a duas importantes conclusões. A primeira concerne aos suscitantes do incidente, ou seja, verificou-se que, dos 14 incidentes distribuídos, 10 foram suscitados por órgãos fracionários do próprio tribunal (Câmaras Cíveis e Seção Cível), o equivalente a $71,4 \%$ do total de incidentes distribuídos. Os incidentes suscitados por juízes de primeiro grau no período correspondem a $14,2 \%$ do total (02 incidentes distribuídos). A Fazenda Pública estadual suscitou 01 incidente, correspondente ao percentual de $7,1 \%$ do total no período e apenas uma pessoa física, na condição de parte autora no Juizado Especial da Fazenda Pública, suscitou o incidente, perfazendo o mesmo percentual $(7,1 \%)$, conforme figura abaixo:

\section{GRÁFICO 4 - Incidentes distribuídos no Tribunal de Justiça do Rio de Janeiro}

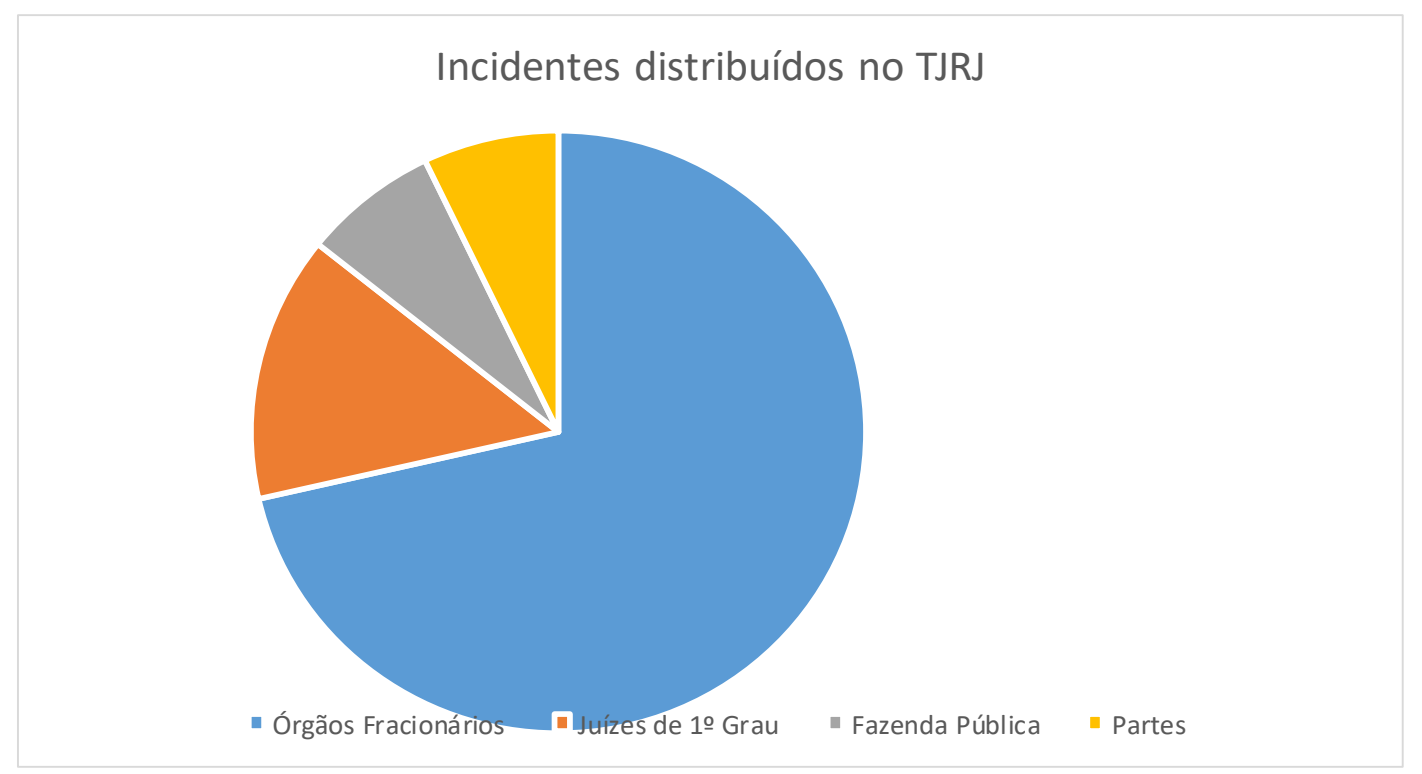

Fonte: Banco nacional de demandas repetitivas do Conselho Nacional de Justiça

A segunda conclusão corresponde à participação de pessoas e entidades interessadas na formação da tese jurídica a ser fixada ${ }^{37}$. Apenas em um incidente foi admitida a participação de amicus curiae. Esse dado é relevante, pois os incidentes tratam de temas com ampla repercussão social e jurídica, como serviço público, tutela coletiva e relação de consumo. Em

36 BRASIL. Tribunal de Justiça do Estado do Rio de Janeiro. Lista de Incidentes de Resolução de Demandas Repetitivas distribuídos. Disponível em: http://www.tjrj.jus.br/documents/10136/3607547/irdr.pdf. Acesso em: 16 maio 2018.

37 BRASIL. Tribunal de Justiça do Estado do Rio de Janeiro. Lista de Incidentes de Resolução de $\begin{array}{lccc}\text { Demandas } & \text { Repetitivas } & \text { distribuídos. } & \text { Disponível } \\ \text { http://www.tjrj.jus.br/documents/10136/3607547/irdr.pdf. Acesso em: } 16 \text { maio } 2018 .\end{array}$ 
alguns poucos casos, há o requerimento de entidades da sociedade civil, mas são indeferidos, em sua maioria.

O cruzamento dos dados coletados no Tribunal de Justiça do Estado do Rio de Janeiro ${ }^{38}$ sugerem a conclusão de que o instituto vem sendo utilizado, de forma considerável, para estabelecer uma padronização decisória de modo a viabilizar a administração da justiça, principalmente no que diz respeito à solução rápida de causas repetitivas. Essa conclusão decorre do alto número de incidentes suscitados pelos órgãos fracionários e juízes de primeiro grau. Entretanto, pouco se avançou no que concerne à participação de outros sujeitos processuais na formação da tese jurídica.

No Tribunal de Justiça do Estado de Minas Gerais os dados sugerem interpretação diversa $^{39}$. No ano de 2016, foram distribuídos 33 incidentes. Nessa amostra, 20 foram suscitados por órgãos fracionários do tribunal (60,6\%), 08 pelas partes (24,2\%), 02 pela Fazenda Pública (6\%), 02 por juízes de primeiro grau (6\%) e 01 pelo Ministério Público (3\%). Dentre os 33 incidentes distribuídos, 07 tiveram a intervenção de amici curiae, tais como OAB, Sindicatos, Bancos, Defensoria Pública do Estado, Associações e Instituto de Previdência do Estado.

Em 2017, essa dinâmica de participação não só se manteve como avançou no número de incidentes distribuídos pelas partes. Foram distribuídos 64 incidentes divididos da seguinte forma: 26 foram suscitados por órgãos fracionários do tribunal $(40,6 \%), 28$ pelas partes $(43,7 \%)$, 06 pela Fazenda Pública (9,3\%), 02 por juízes de primeiro grau (3,1\%), 01 pela Defensoria Pública $(1,5 \%)$ e 01 por uma Associação (1,5\%). Dentre os 64 incidentes distribuídos, 11 tiveram a intervenção de amici curiae, com intensa participação de importantes atores sociais da sociedade mineira. Um dado que merece destaque concerne à ampliação dos incidentes suscitados por associações da sociedade civil e pela Defensoria Pública.

Analisando os dados numa perspectiva integrada, nos dois primeiros anos de vigência do Código de Processo Civil de 2015 foram distribuídos 97 incidentes no tribunal mineiro, sendo que, desse total, 46 foram suscitados por órgãos fracionários do tribunal (47,4\%), 36 pelas partes (37,11\%), 08 pela Fazenda Pública (8,2\%), 04 por juízes de primeiro grau (4,1\%), 01 pela Defensoria Pública (1\%), 01 pelo Ministério Público (1\%) e 01 por uma Associação (1\%). Outro dado importante concerne à atuação dos amici curiae no processo decisório. Dentre os 97

38 BRASIL. Tribunal de Justiça do Estado do Rio de Janeiro. Lista de Incidentes de Resolução de Demandas Repetitivas distribuídos. Disponível em: http://www.tjrj.jus.br/documents/10136/3607547/irdr.pdf. Acesso em: 16 maio 2018.

39 BRASIL. Tribunal de Justiça do Estado de Minas Gerais. Lista de Incidentes de Resolução de Demandas Repetitivas distribuídos. Disponível em: http://www4.tjmg.jus.br/juridico/sf/consulta_nugep.jsp. Acesso em: 16 maio 2018. 
incidentes distribuídos, os amici curiae foram admitidos em 18 , o que corresponde a $18,5 \%$ do total.

Os dados coletados apontam para algumas conclusões importantes. Embora o IRDR seja utilizado, em sua maioria, pelos órgãos fracionários $(47,4 \%)$ como forma de racionalizar a atividade judiciária e uniformizar a jurisprudência, é certo, também, que há alguma democratização no processo de formação da tese jurídica a ser fixada. 0 número considerável de incidentes suscitados pelas partes (37,11\%) e a atuação dos amici curiae em $18,5 \%$ dos incidentes sugere que a democratização do processo decisório proposto pelo Código está em desenvolvimento no tribunal mineiro.

No Tribunal de Justiça do Estado de São Paulo outro quadro se apresenta ${ }^{40}$. No período compreendido entre os anos de 2016 e 2017, 17 incidentes foram distribuídos. Os órgãos fracionários do tribunal suscitaram 08 incidentes (47\%), as partes suscitaram 05 incidentes $(29,4 \%)$, a Fazenda Pública estadual $02(11,7 \%))$ e juízes de primeiro grau $02(11,7 \%)$. Em nenhum processo houve a intervenção de amici curiae ${ }^{41}$.

Interessante observar que, embora o número de incidentes distribuídos no tribunal paulistano seja reduzido, há maior número de incidentes suscitados pelas partes $(29,4 \%)$, o que representa, em alguma medida, a expansão da democratização do procedimento de formação de precedentes judiciais ${ }^{42}$.

Já no Tribunal de Justiça do Rio Grande do Sul ${ }^{43}$ apenas 07 incidentes foram distribuídos entre os anos de 2016 e 2017. Desse universo, 03 foram suscitados pelos órgãos fracionários do tribunal (42,8\%), 02 pelas partes (28,5\%), 01 pela Fazenda Pública (14,2\%) e 01 por juiz de primeiro grau de jurisdição (14,2\%). Em nenhum caso se verificou a atuação de amici curiae. Nos Tribunais de Justiça dos Estados de Goiás e Bahia, o quadro não se distancia muito do tribunal gaúcho.

\footnotetext{
${ }^{40}$ BRASIL. Tribunal de Justiça do Estado de São Paulo. Lista de Incidentes de Resolução de Demandas Repetitivas distribuídos. Disponível em: http://www.tjsp.jus.br/Nurer/Nurer/Irdr. Acesso em: 16 maio 2018.

${ }^{41} \mathrm{Em}$ alguns casos há a nomenclatura requerente e interessados. Não há como se distinguir no andamento processual disponibilizado nos sítios dos tribunais a distinção entre interessados e amigos da corte. Entretanto, a análise de toda amostragem sugere a interpretação de que interessados são partes nos processos que tratam da temática objeto do incidente e amigos da corte são os terceiros que participam do processo decisório, mas não possuem demandas sobre o tema ajuizado.

42 Os incidentes foram suscitados, em sua maioria, por bancos e empresas privadas interessados em obter tese jurídica favorável aos seus eventuais interesses econômicos. No entanto, esse dado revela que não há o monopólio dos órgãos judiciais na instauração do incidente.

43 BRASIL. Tribunal de Justiça do Estado do Rio Grande do Sul. Lista de Incidentes de Resolução de Demandas Repetitivas distribuídos. Disponível em: http://www.tjrs.jus.br/institu/nurer/irdr.php. Acesso em: 16 maio 2018.
} 
$\mathrm{Na}$ Justiça Estadual de Goiás ${ }^{44}$ foram distribuídos 06 incidentes. Os órgãos fracionários foram responsáveis pela distribuição de 03 incidentes (50\%), 01 pelas partes (16,6\%), 01 pelo Ministério Público $(16,6 \%)$ e um incidente não foi possível identificar os respectivos dados, pois não estavam disponíveis no sítio do tribunal. No Estado da Bahia ${ }^{45}$, foram distribuídos somente 07 incidentes, sendo que 06 deles (85,7\%) foram suscitados pela Fazenda Estadual e apenas 01 (14,2\%) por órgão fracionário do tribunal. Em um caso verificou-se a atuação de amicus curiae.

Considerando a totalidade dos dados coletados nos 06 tribunais de justiça de diversas regiões do Brasil, apurou-se o resultado que segue. Foram distribuídos 165 incidentes $^{46}$ entre 2016 e 2017. Nesse período, 71 foram suscitados por órgãos fracionários dos tribunais (43\%), 45 pelas partes (27,27\%), 17 pela Fazenda Pública (10,3\%), 09 por juízes de primeiro grau $(5,4 \%), 02$ pelo Ministério Público (1,2\%), 01 pela Defensoria Pública $(0,6 \%)$ e 01 por Associação $(0,6 \%)$. Os amici curiae ingressaram em 19 incidentes (11,5\%). A figura abaixo permite visualizar os dados mencionados acima.

\section{GRÁFICO 5 - Distribuição do IRDR por legitimado}

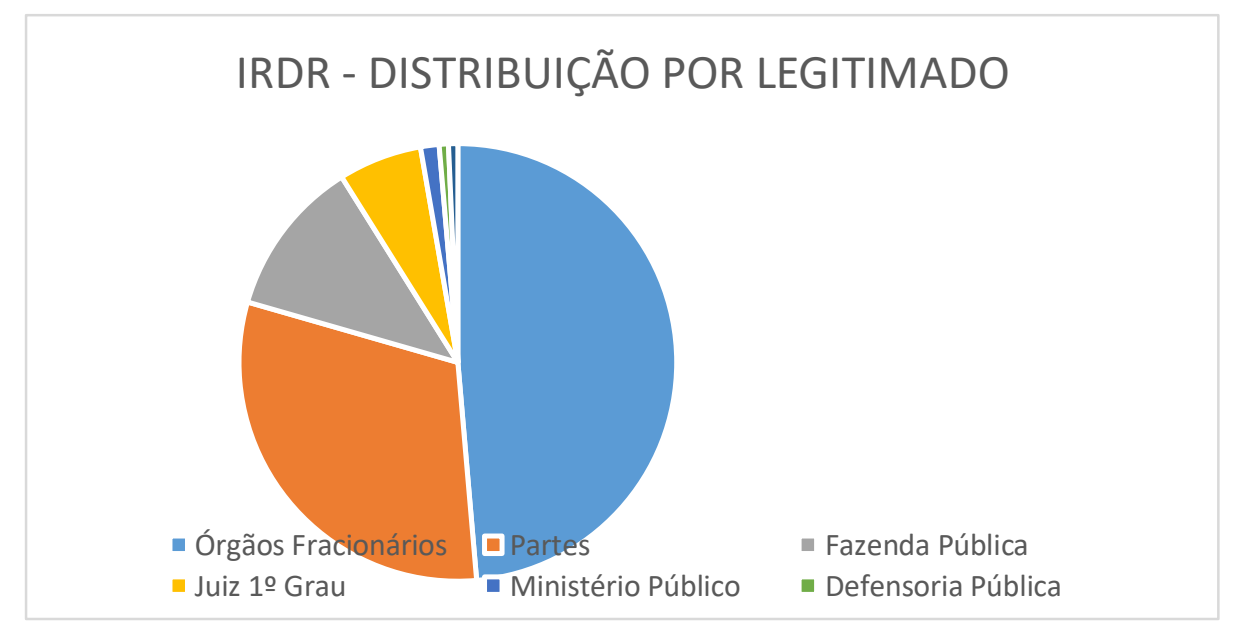

Fonte: Banco nacional de demandas repetitivas do Conselho Nacional de Justiça

\footnotetext{
${ }^{44}$ BRASIL. Tribunal de Justiça do Estado de Goiás. Lista de Incidentes de Resolução de Demandas Repetitivas distribuídos. Disponível em: http://www.tjgo.jus.br/index.php/irdr-nugep. Acesso em $16 / 05 / 2018$.

${ }^{45}$ BRASIL. Tribunal de Justiça do Estado da Bahia. Lista de Incidentes de Resolução de Demandas Repetitivas distribuídos. Disponível em: http://www.tjba.jus.br/nugep/index.php/irdr. Acesso em: 16 maio 2018.

46 Importante registrar que a estatística do CNJ não dialoga com os dados disponíveis no sítio dos estados. Há discrepância entre o número total de incidentes distribuídos entre 2016 e 2017 registrados no sítio do $\mathrm{CNJ}$ e os apontados nos registros dos tribunais dos estados.
} 
Os dados evidenciam que o incidente vem sendo utilizado amplamente pelos órgãos fracionários dos Tribunais de Justiça (43\%). Esse resultado reflete o próprio objetivo da comissão que elaborou o anteprojeto do código, qual seja assegurar maior isonomia no tratamento das causas repetitivas através da padronização decisória. Não há dúvidas, nesse sentido, acerca da ampla utilização dos incidentes pelos tribunais, sobretudo quando se observa a busca pelo Poder Judiciário de meios efetivos para racionalizar a administração da justiça.

Entretanto, o código não pretendeu, somente, assegurar maior efetividade na administração da justiça. Pretendeu-se, também, democratizar o procedimento com a ampliação da participação de terceiros e interessados na formação do processo decisório dos incidentes de jurisprudência uniformizadora, como propõe Mitidiero ${ }^{47}$, ou mesmo edição de precedentes, como pretende Luiz Guilherme Marinoni ${ }^{48}$. O número considerável de incidentes suscitados pelas partes $(27,27 \%)$ e o crescimento gradual da atuação dos amici curiae $(11,5 \%)$ são sintomas de que a democratização do processo civil vem se intensificando em nossa prática forense.

Mas a análise dos dados revela, também, que a democratização não vem se expandindo de forma homogênea na Justiça dos Estados. O Tribunal de Justiça de Minas Gerais foi o que mais registrou a distribuição de incidentes. Foi, também, o tribunal em que houve maior diversidade de legitimados que fizeram uso do incidente. Além dos incidentes suscitados pelos sujeitos processuais, percebeu-se que a Defensoria Pública, Sindicatos e Associações foram, também, responsáveis pela distribuição de incidentes. Em outra perspectiva da análise, o tribunal mineiro admitiu 18 amici curiae, considerando os dados em sua universalidade.

Essa performance democratizante não se verifica em outros tribunais, conforme informam os dados coletados e supramencionados. Tribunais considerados de vanguarda, como o do Rio Grande do Sul, possui baixo índice de utilização do incidente e pouca intensidade na democratização do procedimento ${ }^{49}$. 0 mesmo ocorre com os Tribunais de Justiça dos Estados do Rio de Janeiro, São Paulo e Goiás. No Estado da Bahia o incidente vem sendo utilizado exclusivamente pela Fazenda Pública estadual.

\footnotetext{
${ }^{47}$ MITIDIERO, Daniel, Precedentes Judiciais: da persuasão a vinculação. São Paulo: Revista dos Tribunais, 2017.

${ }^{48}$ MARINONI, Luiz Guilherme. Julgamento nas cortes supremas: precedentes e decisão do recurso diante do novo CPC. São Paulo: Revista dos Tribunais, 2017.

49 Não se pretende afirmar que estes tribunais são conservadores ou qualquer outra inferência neste sentido, mas sugere a preferência por outras técnicas de resolução de conflitos e formação de decisões judiciais paradigmáticas.
} 
Essa dinâmica procedimental, revelada pela amostra que compõe o presente estudo, sugere a existência de, pelos menos, três tipos ideais de Tribunais de Justiça, para utilizar as categorias weberianas ${ }^{50}$. 0 primeiro tipo ideal é composto por tribunais em que a dinâmica de julgamento do IRDR é marcado por um amplo debate com a participação intensa das instituições jurídicas, como o Ministério Público e a Defensoria Pública, e também de entidades da sociedade civil, como associações e sindicatos, seja através da suscitação do incidente ou da atuação como amicus curiae. Pode-se afirmar, portanto, que esse tipo ideal é marcado por maior intensidade na democratização do processo decisório, como ocorre no Tribunal de Justiça de Minas Gerais.

O segundo tipo ideal refere-se aos tribunais com média intensidade de democratização. São os tribunais em que os incidentes são suscitados em sua maioria pela Fazenda Pública, estadual e municipal, ou pelas partes, principalmente bancos e empresas, mas que não há participação e democratização do debate através da admissão dos amici curiae. É o que se observa, em alguma medida, no Tribunal de Justiça da Bahia e do Rio Grande do Sul.

Em outra linha de análise, o terceiro tipo ideal concerne aos tribunais em que os conflitos são suscitados majoritariamente pelos órgãos fracionários e juízes de primeira instância, com a finalidade de assegurar a jurisprudência uniformizadora com baixa intensidade de democratização, considerando que não há, conforme sugerem os dados, ampla participação dos sujeitos processuais e dos amici curiae.

Essa tipologia weberiana permite refletir sobre dois importantes aspectos. 0 primeiro é que não há como se pensar numa cultura jurídica processual brasileira uniforme. Cada tribunal local estrutura sua visão de processo e de participação e isso se reflete no processo de formação da tese jurídica fixada no julgamento do Incidente de Resolução de Demandas Repetitivas.

Outro aspecto importante a ser considerado diz respeito ao grau de associativismo e organização da sociedade civil em determinado Estado reflete diretamente na democratização do processo civil. Nessa linha de análise, a crença, ou não, da sociedade civil no Poder Judiciário interfere de forma decisiva nessa questão. Essas variáveis dependentes são fundamentais para estudar e compreender a democratização do processo proposta pelo código e sua aplicabilidade na sociedade brasileira.

\footnotetext{
${ }^{50}$ Max Weber utilizou como método de análise em seus estudos sociológicos os tipos ideais. Tipos ideais são tipologias, sem conteúdo valorativo, que permite ao pesquisador elaborar recurso analítico com base em conceitos mais amplos. Os tipos ideais não retratam a realidade, mas constituem categoriais analíticas que permite estudar e compreender de forma mais ampla um aspecto da realidade social. Ver ARON, Raymond. As etapas do pensamento sociológico. 3. ed. São Paulo: Martins Fontes, 1990. p. 482.
} 
Neste mesmo contexto, a ampliação das possibilidades de realização de audiência pública, no âmbito dos tribunais locais e nas cortes superiores, constitui dimensão democratizante importante do Código de Processo Civil de 2015. A democratização da audiência pública no âmbito da jurisdição constitucional já foi objeto de substanciosos estudos ${ }^{51}$. Há certo consenso acerca da intensidade da participação da sociedade civil e dos movimentos sociais nos processos, objetivos ou subjetivos, com forte repercussão jurídica, política e social. A divergência permanece no que concerne ao grau de influência desses atores na formação da decisão judicial.

Considerando o recorte do presente estudo, interessa investigar em que medida a expansão do regramento da audiência pública ampliou a sua utilização no Poder Judiciário brasileiro. No âmbito do Supremo Tribunal Federal ${ }^{52}$ não houveram maiores repercussões. Somente 05 audiências públicas foram agendadas entre os anos de 2016 e 2017. São elas: a) Aplicabilidade do direito ao esquecimento na esfera civil, em especial quando esse for invocado pela própria vítima ou por seus familiares, realizada no dia 12 de junho de 2017 (RE 1010606 Min. Dias Toffoli53); b) Audiência pública simultânea convocada para discutir aspectos dos artigos 10 e 12, II e IV, da Lei n 12.965/2014 - Marco Civil da Internet (ADI 5.527, Rel. Min. Rosa Weber) e a Suspensão do aplicativo WhatsApp por decisões judiciais no Brasil (ADPF 403, Rel. Min. Edson Fachin), realizadas nos dias 02/06/17 e 05/06/2017; c) Armazenamento de perfis genéticos de condenados por crimes violentos ou hediondos, realizada no dia 25/05/2017 (RE 937837 - Min. Gilmar Mendes); d) Novo Código Florestal, realizada no dia 18 de abril de 2016 (ADI n 4.901, ADI $n^{\circ} 4.902$, ADI n 4.903, ADI n 4.937 - Min. Luiz Fux).

No âmbito do Superior Tribunal de Justiça ${ }^{54}$ foi realizada, até maio de 2018, somente a audiência pública sobre conceito de capitalização de juros, no dia 29/02/2016, e a audiência

51 CATHARINA, Alexandre de Castro Catharina. Movimentos sociais e a construção dos precedentes judiciais. Curitiba: Juruá, 2015. FILHO, Roberto Fragale. Audiências públicas e seu impacto no processo decisório: ADPF 54 como estudo de caso. Revista eletrônica Direito \& Práxis, Rio de Janeiro, RJ, v. 6, n. 3, p. 504-536, nov. 2015. ISSN 2179-8966. DOI: 10.12957/dep.2015.19230. Disponível em: https://www.epublicacoes.uerj.br/index.php/revistaceaju/article/view/19230/14049. Acesso em: 20 maio 2018. VALLE, Vanice Regina Lírio do (Org.). Audiências públicas e ativismo: diálogo social no STF. Belo Horizonte: Fórum, 2012.

52 BRASIL. Supremo Tribunal Federal. Audiências públicas realizadas. Disponível em: http://www.stf.jus.br/portal/audienciaPublica/audienciaPublica.asp?tipo=realizada. Acesso em 20 maio 2018.

${ }^{53}$ Acesso em: 01 out. 2017.

${ }^{54}$ Brasil. Superior Tribunal de Justiça. Pesquisa sobre realização de audiências públicas. Disponível em: http://www.stj.jus.br/sites/portalp/Comunicacao/Informacoes-a-imprensa/Informacoes-essenciais-sobreprocessos. Acesso em 20 maio 2018. 
pública para debate sobre a legalidade da cobrança de taxas na venda de imóvel, realizada em 09/05/2016.

Percebe-se, com efeito, que não houve praticamente nenhum impacto do Código de Processo Civil na dinâmica das audiências públicas. Elas continuam sendo realizadas no modelo estabelecido na jurisdição constitucional, antes mesmo do advento do CPC/2015. Por outro lado, não há, ainda, realização de audiências públicas designadas para alteração ou revisão de tese fixada em precedentes judiciais nos tribunais locais. Tal fato decorre, naturalmente, do curto período de vigência do código. Destaca-se, portanto, que o tratamento do tema no CPC reflete a importância desse ato na atividade jurisdicional num Estado Democrático de Direito.

Se faz necessário, portanto, aprofundar a reflexão acerca do papel do amicus curiae no processo civil contemporâneo. A inclusão do amicus curiae no Título III, Capítulo V, como intervenção de terceiros em qualquer grau de jurisdição, foi, sem dúvida, importante avanço na democratização do processo. 0 Código de Processo Civil optou pelo método de julgamento de casos paradigmáticos e repetitivos. Nesse contexto, o juiz de primeiro grau pode julgar uma determinada causa com forte repercussão social, como uma ação possessória sobre imóvel ocupado por movimentos sociais ou inúmeros cidadãos, ou mesmo julgar casos em que se discute aumento abusivo de plano de saúde. Casos dessa envergadura podem, inclusive, ensejar a suscitação do Incidente de Resolução de Demandas Repetitivas.

É nesse cenário que o código ampliou o espectro de atuação dos amici curiae, nos termos do artigo 138, de modo a permitir que cidadãos e entidades da sociedade civil, que serão afetados pela decisão proferida no processo paradigma, participem da construção da decisão judicial a partir da fase de conhecimento. Essa modalidade de intervenção de terceiros, constitui, por si só, importante instrumento de democratização do processo civil.

A atuação dos amici curiae na jurisdição constitucional é significativa e demonstra, de forma peremptória, o amadurecimento da visão dos representantes da sociedade civil e dos movimentos sociais com diversos escopos sociais e políticos acerca da importância na participação dos julgamentos de temas voltados para os direitos fundamentais ${ }^{55}$. No entanto, se

\footnotetext{
${ }^{55}$ Claudio Pereira Neto e Daniel Sarmento tratam da temática em um importante resumo critico acerca da jurisdição constitucional no Brasil. Ao discutir a questão da dificuldade contramajoritária, e as possibilidades de sua superação no âmbito da jurisdição constitucional, os autores abordam a vertente teórica que defende a hipótese de que a participação democrática dos amici curiae em nosso processo constitucional seria fundamental para tornar a jurisdição constitucional uma espécie de "representação argumentativa" da sociedade brasileira, o que afastaria, pelo menos em tese, o argumento contramajoritário. A abordagem dos autores parte, portanto, do mesmo diagnóstico apontado neste trabalho. Para maior aprofundamento da temática ver PEREIRA NETO, Claudio de Souza; SARMENTO,
} 
faz necessário investigar se a extensão da atuação dos amigos da corte no primeiro grau de jurisdição vem ocorrendo em nossa prática forense.

Não há como localizar, no sítio dos tribunais, os processos que admitiram os amici curiae em primeiro grau de jurisdição. Somente é possível verificar, em pesquisas realizadas na segunda instância, os recursos interpostos contra decisão que inadmitiu o ingresso do amicus curiae. A partir dessa busca se pode, ainda que de forma precária, dimensionar a democratização do processo civil através desse instrumento.

Foram identificados 66 acórdãos que julgaram questões concernentes à admissão de amici curiae em processos que tramitam em primeiro grau de jurisdição ${ }^{56}$. No Tribunal de Justiça do Rio Grande do Sul ${ }^{57}$ foram localizados 18 acórdãos, no Tribunal de Justiça do Estado do Rio de Janeiro foram localizados 29 acórdãos ${ }^{58}$, no Tribunal de Justiça do Estado de Goiás ${ }^{59} 06$ acórdãos e no Tribunal de Justiça de Minas Gerais ${ }^{60}$ foram encontrados 13 acórdãos. No Tribunal de Justiça do Estado de São Paulo não foi possível identificar na amostra quais os casos que trataram de admissão de amici curiae, vez que o sítio não destaca as palavras selecionadas na pesquisa.

Se faz importante destacar que esses dados são precários pois decorrem de recursos interpostos, em sua maioria, contra decisões que inadmitiram o ingresso do amigo da corte. Os requerimentos de ingresso admitidos não estão contabilizados no número mencionado acima. Há, portanto, indícios de que a participação da sociedade nos processos judiciais, envolvendo

Daniel. Notas sobre jurisdição constitucional e democracia: a questão da "última palavra" e alguns parâmetros de autocomposição judicial. Revista Quaestio luris, Rio de Janeiro, RJ, v. 6, n 2, p. 131.

${ }^{56}$ A consulta foi realizada no sítio dos Tribunais de Justiça dos estados do Rio de Janeiro, São Paulo, Minas Gerais, Rio Grande do Sul, Goiás e Bahia.

57 BRASIL. Tribunal de Justiça do Estado do Rio Grande do Sul. Disponível em: http://www.tjrs.jus.br/site/busca-solr/index.html?aba=jurisprudencia. Acesso em 16 maio 2018.

58 BRASIL, Tribunal de Justiça do Estado do Rio de Janeiro. Disponível em: http://conhecimento.tjrj.jus.br/web/portal-conhecimento/jurisprudencia. Acesso em 16 maio 2018.

59 BRASIL. Tribunal de Justiça do Estado de Goiás. Disponível em: https://www.tjgo.jus.br/jurisprudencia/juris.php. Acesso em 16 maio 2018.

60 BRASIL. Tribunal de Justiça de Minas Gerais. Lista de acórdãos sobre admissão de amici curiae Disponível em: http://www5.tjmg.jus.br/jurisprudencia/pesquisaPalavrasEspelhoAcordao.do;jsessionid=36B6A57E283576 AOBFEFFC2AAC5FA7EE.juri_node1?numeroRegistro=1\&totalLinhas=1\&palavras=amicus+curiae\&pesquisarPor $=$ ementa\&pesquisaTesauro=true\&torderByData $=1 \&$ codigoOrgaoJulgador $=\&$ codigoCompostoRelator $=\&$ classe $=$ \&codigoAssunto=\&dataPublicacaolnicial=\&dataPublicacaoFinal=\&dataJulgamentolnicial $=01 \% 2 \mathrm{~F} 01 \% 2 \mathrm{~F} 2016 \&$ dataJulgamentoFinal=31\%2F12\%2F2017\&siglaLegislativa=\&referenciaLegislativa=Clique+na+lupa+para+pesq uisar+as+refer\%EAncias+cadastradas...\&numeroRefLegislativa=\&anoRefLegislativa=\&legislacao=\&norma=\& descNorma=\&complemento_1=\&listaPesquisa=\&descricaoTextosLegais=\&observacoes=\&linhasPorPagina=10 \&pesquisaPalavras=Pesquisa. Acesso em: 16 maio 2018. 
temas como direito administrativo, direito do consumidor e direito tributário, apenas para exemplificar, vem aumentando de forma significativa.

Esse dado revela que a sociedade vem acentuando a sua participação nos processos judiciais com maior repercussão jurídica, política e social, o que evidencia que a democratização do processo civil se intensificou na medida em que amadurece a compreensão acerca do Código de Processo Civil. 0 acórdão proferido pelo Tribunal de Justiça do Estado do Rio de Janeiro, no julgamento do Agravo de Instrumento $n^{\circ}$ 0055278-59.2015.8.19.0000, Julgado em 26/07/2016, é emblemático neste sentido, pois utilizou como fundamento determinante para admissão do amicus curiae um argumento em defesa da democratização do processo, conforme transcrição abaixo:

A figura do amicus curiae (amigo da corte) surge como um dos realizadores desta tarefa: um interveniente especial que se empenha na função de colaborador do magistrado, seja prestando informações necessárias ao julgamento da lide ou se manifestando no interesse daqueles que não têm a possibilidade de atuar pessoalmente em uma determinada demanda. A razão de ser desta figura processual é pluralizar o debate, colocar em pratica a adoção do princípio democrático, de modo que outros órgãos ou entidades possam participar e influenciar a tomada de decisões que apresentem relevância para a sociedade. ${ }^{61}$

A expansão da atuação do amigo da corte no processo representou, em verdade, a incorporação de um modelo participativo do processo decisório amadurecido na práxis da jurisdição constitucional.

\section{A TENSÃO ENTRE A CULTURA JURÍDICA ESTABELECIDA E A DEMOCRATIZAÇÃO DO PROCESSO PROPOSTA NO CPC}

Os dados apresentados acima revelam traços importantes da cultura jurídica processual brasileira e as tensões que se manifestaram a partir da vigência do Código de Processo Civil de 2015. Uma primeira conclusão que se extrai da análise dos dados é que qualquer reforma processual, seja ela ampla ou restrita, deve considerar a cultura jurídica processual estruturada em determinada sociedade.

\footnotetext{
${ }^{61}$ BRASIL. Tribunal de Justiça do Estado do Rio de Janeiro. Acórdão de decisão que reforçou a admissão de amicus curiae. Agravo de instrumento $\mathrm{n}^{\circ}$ 0055278-59.2015.8.19.0000. Ordem dos Advogados do Brasil, Seção do Estado do Rio de Janeiro, $57^{a}$ Subseção da Barra da Tijuca e Ministério Público. Relator: Desembargador Fabio Dutra. 26 de julho de 2016. Disponível em: http://www4.tjrj.jus.br/ejud/ConsultaProcesso.aspx?N=201500261314. Acesso em: 16 maio 2018.
} 
Há, nesse sentido, reformas processuais que reforçam os traços fundantes de uma determinada cultura jurídica. No Brasil, alguns reflexos dessa cultura jurídica podem ser identificada na ampliação dos poderes do relator no julgamento de recursos ${ }^{62}$, conforme artigo 557 do CPC/73, com redação dada pela Lei $n^{\circ}$ 9.756/98. Tal inovação está em consonância com a cultura jurídica processual fortemente assentada na suposta capacidade hercúlea do julgador brasileiro para solucionar adequadamente conflitos. Em outra perspectiva, a referida reforma viabilizou a busca do Poder Judiciário pela racionalização no julgamento de demandas repetitivas ou seriais. O alto número de Incidentes de Resolução de Demandas Repetitivas corrobora essa percepção.

No entanto, há reformas processuais que destoam da cultura jurídica processual e, portanto, não produzem resultados práticos na prática forense. Pode-se citar, como exemplo, a designação de audiência de conciliação prévia nos termos do artigo 331 do CPC/73. 0 baixíssimo índice de aplicação fez com que a regra fosse relativizada na prática forense. Tal resultado decorre da baixa adesão da sociedade brasileira aos meios alternativos de solução de conflitos.

O Código de Processo Civil de 2015 traz em seu bojo regras que retroalimentam a cultura jurídica estabelecida, como a compreensão de que a Fazenda Pública deve ter tratamento diferenciado para a prática de atos processuais (artigo 183), entre outros exemplos, mas inova ao trazer dispositivos que estimulam a democratização do processo decisório.

Os dados mostram que, em 02 anos de vigência do CPC/2015, pode-se identificar casos de alto grau ou intensidade de democratização do processo decisório no IRDR, como ocorre no Tribunal de Justiça de Minas Gerais. Entretanto, nos demais casos, a democratização no IRDR ainda é muito incipiente. Esses dados refletem a tensão entre o conteúdo normativo do CPC/2015 e a cultura jurídica tecnicista dos tribunais brasileiros.

Em outra perspectiva, o número considerável de requerimento de ingresso de amici curiae em parte considerável da amostra retrata uma nova dimensão democrática do processo decisório na primeira instância. Esse dado revela, também, que a cultura jurídica processual pode ser reestruturada a partir da atuação da sociedade. É nesse sentido que o conceito de reflexividade de Oscar Chase ${ }^{63}$ nos ajuda a pensar o processo civil brasileiro. Para o autor, as instituições de resolução de conflitos desempenham papel essencial no processo contínuo de manutenção e reconstrução das práticas e normas sociais.

62 BRASIL. Lei n'9.756, de 17 de dezembro de 1998. Dispõe sobre o processo recursos no âmbito dos tribunais. Diário Oficial da União. Brasília. DF. 18 dez. 1998. Disponível em: http://www.planalto.gov.br/ccivil_03/LEIS/L9756.htm. Acesso em: 17 maio 2018.

${ }^{63}$ CHASE, Oscar. Direito, cultura e ritual: sistemas de resolução de conflitos e no contexto da cultura comparada. São Paulo, Marcial Pons, 2014. 
Essa perspectiva teórica contribui para compreender a relação tensa entre a cultura jurídica processual estabelecida e as dimensões democratizantes do CPC/2015. Embora Chase tenha pensado a cultura jurídica processual norte-americana a partir da comparação com o sistema de resolução de conflitos da tribo africana Azande, seus conceitos e categorias podem ser utilizadas para se pensar a processualística brasileira, dada a similaridade, do ponto de vista do pluralismo cultural e étnico, entre a sociedade brasileira e americana ${ }^{64}$.

Segundo Chase, o processo de resolução de conflitos de determinada sociedade reflete a cultura, os valores sociais, o arranjo social e o próprio sistema simbólico. Mas essa relação é reflexiva, de modo que o processo de resolução de conflitos será também um componente desse movimento contínuo de manutenção e reconstrução da cultura que está inserido. 0 argumento central da tese do autor pode ser sintetizado na seguinte passagem:

[...] minha teoria a respeito do processo terá utilidade tanto em uma perspectiva de previsão quanto em um aspecto normativo: ela servirá para prever que quando a cultura passa por mudanças significativas, quaisquer que sejam seus motivos, o processo possivelmente irá se adequar à nova roupagem. A recíproca é verdadeira: modificações no processo apresentarão impacto mais amplo. Já no prisma normativo, esta análise adverte os legisladores quanto á necessidade de, ao adaptarem o processo, terem em mente o impacto cultural em potencial que é inerente a tal opção. Não há, assim, reforma processual que possa ser pensada somente sob a reforma da técnica jurídica. ${ }^{65}$

Essa perspectiva dinâmica da cultura jurídica processual contempla a possibilidade de superação de uma cultura jurídica processual liberal e centrada no solipsismo do julgador por uma cultura jurídica processual mais abrangente e inclusiva. Nesse contexto, as dimensões democratizantes do CPC/2015, embora não retratem a cultura jurídica estabelecida, em alguma medida refletem a dinâmica de participação da sociedade brasileira na jurisdição constitucional. E é a partir dessa tensão que será possível transformar, progressivamente, a cultura jurídica processual brasileira para se estabelecer um processo civil democrático, inclusivo, onde a decisão será, de fato, resultado da cooperação entre juiz, partes e terceiros interessados.

Nessa mesma linha de análise, Gustavo Osna ${ }^{66}$, ao analisar os desafios do Código de Processo Civil de 2015, destaca que a Lei $n^{\circ} 13.105 / 2015$ foi pensada sob a égide de um regime

\footnotetext{
${ }^{64}$ CHASE, Oscar. Direito, cultura e ritual: sistemas de resolução de conflitos e no contexto da cultura comparada. São Paulo, Marcial Pons, 2014.

${ }^{65}$ CHASE, Oscar. Direito, cultura e ritual: sistemas de resolução de conflitos e no contexto da cultura comparada. São Paulo, Marcial Pons, 2014, p. 187.

${ }^{66}$ OSNA, Gustavo. Processo civil, cultura e proporcionalidade: análise crítica da teoria processual. São Paulo: Revista dos Tribunais, 2017.
} 
democrático, razão pela qual caberia ao processo civil concretizar a noção de democracia. 0 caminho para tanto, na perspectiva do autor, seria a recomposição da relação processual de modo a assegurar maior paridade entre os sujeitos processuais, em detrimento de um modelo processual onde a centralização dos poderes está nas mãos do juiz. Se faz necessário ir além do tecnicismo processual e estabelecer, a partir da cultura, um processo civil democrático.

Essa perspectiva teórica é essencial para superar o modelo tradicional de processo e tem como principal mérito a construção de uma nova epistemologia do processo civil, onde a ênfase na técnica processual, auto referenciada, é substituída por uma perspectiva participativa, democrática e inclusiva do processo decisório. Esse modelo de processo não decorre de abstrações teóricas, mas das dimensões democratizantes do Código de Processo Civil de 2015 tratadas ao longo desse trabalho.

\section{CONCLUSÃO}

A cultura jurídica processual estabelecida no Brasil, desde os primórdios da formação jurídica, social e política do país, tem sido essencial para a retroalimentação de um modelo de processo individualizante e excludente, na medida que tem como principal objeto questões patrimoniais. Entretanto, a prática judiciária, sobretudo a partir da Constituição Federal de 1988, vem contribuindo para a transformação social a partir da consolidação de um novo modelo cooperativo e democrático de processo.

As dimensões democratizantes do Código de Processo Civil de 2015 provocaram, pelo que foi apresentado acima, uma mudança paradigmática na processualística. A principal renovação foi a proposta de superação de um modelo liberal de processo civil para se estabelecer um modelo democrático de processo. Essa amálgama normativa ensejou importantes abalos na cultura jurídica processual estabelecida, afastando, de alguma maneira, o monopólio do processo decisório pelo juiz. Essa onda renovatória resulta da mudança na percepção que a própria sociedade organizada tem do Poder Judiciário, não mais exclusivamente como um poder hierarquizado, mas, em certa perspectiva, como um espaço de construção de novas sociabilidades.

Portanto, percebeu-se o alvorecer consistente, do ponto de vista teórico, conceitual e pragmático, de um modelo democrático de processo civil que traz, como principal efeito, a transformação gradual e permanente da cultura jurídica processual para torná-la abrangente, dialógica e inclusiva. Os dados apresentados no trabalho, ainda que se constitua como uma 
amostra dessa dinâmica institucional, refletem que há mudanças importantes na prática judiciária em desenvolvimento. A ampliação da participação da sociedade civil em processos judiciais e incidentes, em alguns tribunais, são evidências de que a democratização do processo civil não é somente uma proposta legislativa, mas algo identificado empiricamente.

Esse dado aponta para uma tensão existente entre a cultura jurídica estabelecida e um modelo democratizante de processo em curso. A principal conclusão do estudo levado a efeito é no sentido de que essa tensão será fundamental para a superação do pensamento jurídico tradicional, forjado na vigência dos códigos de 1939 e 1973, e da cultura jurídica que lhe dá sustentação, promovendo o estabelecimento gradual e permanente de uma outra cultura jurídica, democratizante e inclusiva. Essa transformação não decorre da mudança na concepção de julgamento por parte do Poder Judiciário, mas em razão da expansão da participação da sociedade na formação das decisões judiciais com forte repercussão social.

E é exatamente a partir dessa perspectiva democratizante de processo que foi possível pensar num novo escopo do direito processual civil para além de um método de solução de conflitos ou mesmo como meio de administração de interesses privados. Um modelo de processo voltado para promoção da consolidação da democracia, no sentido político do termo, e do fortalecimento do Estado democrático do direito.

Esse foi o principal vetor emancipatório decorrente da superação do paradigma liberal e individualizante, que fundou a cultura jurídica processual brasileira, que vem sendo assimilado, gradualmente, por importantes segmentos da práxis judiciária e da literatura especializada analisada acima.

\section{REFERÊNCIAS}

ARON, Raymond. As etapas do pensamento sociológico. 3. ed. São Paulo: Martins Fontes, 1990. BRASIL. Conselho Nacional de Justiça. Banco Nacional de Demandas Repetitivas e Precedentes obrigatórios. Disponível em:

https: / / paineis.cnj.jus.br/QvAJAXZfc/opendoc.htm?document=qvw_l\%2FPainelCNJ.qvw\&host=Q VS\%40neodimio03\&anonymous=true\&sheet=shDRGraficos. Acesso em: 16 maio 2018.

BRASIL. Lei n9.756, de 17 de dezembro de 1998. Dispõe sobre o processo recursos no âmbito dos tribunais. Diário Oficial da União. Brasília. DF. 18 dez. 1998. Disponível em:

http://www.planalto.gov.br/ccivil_03/LEIS/L9756.htm. Acesso em: 17 maio 2018.

BRASIL. Lei ${ }^{\circ} 9.868$, de 10 de novembro de 1999. Dispõe sobre o processo e julgamento da ação direta de inconstitucionalidade e da ação declaratória de constitucionalidade perante o Supremo 
Tribunal Federal. Diário Oficial da União. Brasília. DF. 11 nov. 1999. Disponível em: http://www.planalto.gov.br/ccivil_03/leis/19868.htm. Acesso em: 15 maio 2018.

BRASIL. Lei n $^{\circ} 9.882$, de 03 de dezembro de 1999. Dispõe sobre o processo e julgamento da arguição de descumprimento de preceito fundamental, nos termos do $\$ 1^{\circ}$ do art. 102 da Constituição Federal. Diário Oficial da União. Brasília. DF. 06 dez. 1999. Disponível em: http://www.planalto.gov.br/ccivil_03/leis//9882.htm. Acesso em: 15 maio 2018.

BRASIL. Lei n¹3.105, de 16 de março de 2015. Código de Processo Civil. Diário Oficial da União. Brasília, DF. 17 mar 2015. Disponível em: http://www.planalto.gov.br/ccivil_03/_ato20152018/lei/l13105.htm. Acesso em: 15 maio 2018.

BRASIL. Tribunal de Justiça do Estado de São Paulo. Lista de Incidentes de Resolução de Demandas Repetitivas distribuídos. Disponível em: http://www.tjsp.jus.br/Nurer/Nurer//rdr. Acesso em: 16 maio 2018.

BRASIL. Tribunal de Justiça do Estado do Rio de Janeiro. Lista de Incidentes de Resolução de Demandas Repetitivas distribuídos. Disponível em: http://www.tjrj.jus.br/documents/10136/3607547/irdr.pdf. Acesso em: 16 maio 2018.

BRASIL, Tribunal de Justiça do Estado do Rio de Janeiro. Pesquisa de jurisprudência. Disponível em: http://conhecimento.tjrj.jus.br/web/portal-conhecimento/jurisprudencia. Acesso em 16 maio 2018.

BRASIL. Tribunal de Justiça do Estado do Rio de Janeiro. Acórdão de decisão que reforçou a admissão de amicus curiae. Agravo de instrumento $n^{\circ}$ 0055278-59.2015.8.19.0000. Ordem dos Advogados do Brasil, Seção do Estado do Rio de Janeiro, $57^{\text {a }}$ Subseção da Barra da Tijuca e Ministério Público. Relator: Desembargador Fabio Dutra. 26 de julho de 2016. Disponível em: http: //www4.tjrj.jus.br/ejud/ConsultaProcesso.aspx?N=201500261314. Acesso em: 16 maio 2018.

BRASIL. Tribunal de Justiça do Estado do Rio Grande do Sul. Lista de Incidentes de Resolução de Demandas Repetitivas distribuídos. Disponível em:

http://www.tjrs.jus.br/institu/nurer/irdr.php. Acesso em: 16 maio 2018.

BRASIL. Tribunal de Justiça do Estado do Rio Grande do Sul. Pesquisa de jurisprudência. Disponível em: http://www.tjrs.jus.br/site/busca-solr/index.html?aba=jurisprudencia. Acesso em 16 maio 2018.

BRASIL. Tribunal de Justiça do Estado de Goiás. Lista de Incidentes de Resolução de Demandas Repetitivas distribuídos. Disponível em: http://www.tjgo.jus.br/index.php/irdr-nugep. Acesso em 16/05/2018.

BRASIL. Tribunal de Justiça do Estado de Goiás. Pesquisa de jurisprudência. Disponível em: https://www.tjgo.jus.br/jurisprudencia/juris.php. Acesso em 16 maio 2018.

BRASIL. Tribunal de Justiça do Estado da Bahia. Lista de Incidentes de Resolução de Demandas Repetitivas distribuídos. Disponível em: http://www.tjba.jus.br/nugep/index.php/irdr. Acesso em: 16 maio 2018. 
BRASIL. Tribunal de Justiça do Estado de Minas Gerais. Lista de Incidentes de Resolução de Demandas Repetitivas distribuídos. Disponível em:

http://www4.tjmg.jus.br/juridico/sf/consulta_nugep.jsp. Acesso em: 16 maio 2018.

BRASIL. Tribunal de Justiça de Minas Gerais. Lista de acórdãos sobre admissão de amici curiae. Disponível em:

http: / /www5.tjmg.jus.br/jurisprudencia/pesquisaPalavrasEspelhoAcordao.do;jsessionid=36B6A5 7E283576A0BFEFFC2AAC5FA7EE. juri_node1?numeroRegistro=1\&totalLinhas=1\&palavras=amicus+C uriae\&pesquisarPor=ementa\&pesquisaTesauro=true\&orderByData=1\&codigoOrgaoJulgador $=\&$ codi goCompostoRelator=\&classe=\&codigoAssunto=\&dataPublicacaolnicial=\&dataPublicacaoFinal=\&da taJulgamentolnicial=01\%2F01\%2F2016\&dataJulgamentoFinal=31\%2F12\%2F2017\&siglaLegislativa $=\&$ referenciaLegislativa $=$ Clique+na+lupa+para+pesquisar+as+refer\%EAncias+cadastradas...\&numero $\underline{\text { RefLegislativa=\&anoRefLegislativa=\&legislacao=\&norma=\&descNorma=\&complemento_1=\&listaP }}$ esquisa=\&descricaoTextosLegais=\&observacoes=\&linhasPorPagina=10\&pesquisaPalavras=Pesquisa Acesso em: 16 maio 2018.

CATHARINA, Alexandre de Castro. Movimentos sociais e a construção dos precedentes judiciais. Curitiba: Juruá, 2015.

CATHARINA, Alexandre de Castro. Ensino jurídico e reflexões sobre o novo Código de Processo Civil. In: BASTOS, Aurélio Wander. Os cursos jurídicos no Brasil- 190 anos. Rio de Janeiro: IAB Nacional, 2017.

CHASE, Oscar G. Direito, cultura e ritual: sistemas de resoluções de conflitos no contexto da cultura comparada. Tradução Sergio Arenhart, Gustavo Osna. São Paulo: Marcial Pons, 2014.

FILHO, Roberto Fragale. Audiências públicas e seu impacto no processo decisório: ADPF 54 como estudo de caso. Revista eletrônica Direito \& Práxis, Rio de Janeiro, RJ, v. 6, n. 3, p. 504-536, nov. 2015. ISSN 2179-8966. DOI: 10.12957/dep.2015.19230. Disponível em: https://www.epublicacoes.uerj.br/index.php/revistaceaju/article/view/19230/14049. Acesso em: 20 maio 2018.

HABERMAS, Jurguen. Direito e Democracia: entre a facticidade e validade. 2. ed. Rio de Janeiro: Tempo Brasileiro, 2003.

KOERNER, Andrei. Judiciário e cidadania na constituição da República brasileira (1841-1920). 2. ed. Curitiba: Juruá, 2010.

KOERNER, Andrei. Decisão Judicial, Instituições e Estrutura Socioeconômica: Por uma Análise Política do Pensamento Jurídico Brasileiro. In: KOERNER, Andrei. (Org.) História da Justiça Penal no Brasil: Pesquisas e Análises. São Paulo: IBCCRIM, 2006. p. 259-281.

MARINONI, Luiz Guilherme. Julgamento nas cortes supremas: precedentes e decisão do recurso diante do novo CPC. São Paulo: Revista dos Tribunais, 2017.

MARINONI, Luiz Guilherme. Teoria Geral do Processo. 3. ed. São Paulo: Revista dos Tribunais, 2008. 
MENDES, Aluisio Gonçalves de Castro. Incidente de resolução de demandas repetitivas: sistematização, análise e interpretação do novo instituto processual. Rio de Janeiro: Forense, 2017.

MITIDIERO, Daniel. Precedentes judiciais: da persuasão à vinculação. São Paulo: Revista dos Tribunais, 2017.

NUNES, Dierle José Coelho. Processo jurisdicional democrático: uma análise crítica das reformas processuais. Curitiba: Juruá, 2012.

OSNA, Gustavo. Processo civil, cultura e proporcionalidade: análise crítica da teoria processual. São Paulo: Revista dos Tribunais, 2017.

PEREIRA NETO, Claudio de Souza; SARMENTO, Daniel. Notas sobre jurisdição constitucional e democracia: a questão da "última palavra" e alguns parâmetros de autocomposição judicial. In: Revista Quaestio luris, Rio de Janeiro, RJ, v. 6, n 2, p. 119-161, 2013. ISSN 1516-0351, Disponível em: http://www.e-ublicacoes.uerj.br/index.php/quaestioiuris/article/view/11767. doi: 10.12957/rqi.2013.9321. Acesso em: 27 maio 2018

THEODORO JUNIOR, Humberto; NUNES, Dierle. BAHIA, Alexandre de Melo Franco; PEDRON, Flavio Quinaud. Novo CPC: Fundamentos e sistematização. 2. ed. Rio de Janeiro, Forense, 2015.

VALLE, Vanice Regina Lírio do (Org.). Audiências públicas e ativismo: diálogo social no STF. Belo Horizonte: Fórum, 2012.

WERNECK VIANNA, Luiz; CARVALHO, Maria Alice Rezende de; MELO, Manuel Palacios Cunha; BURGOS, Marcelo Baumann. A judicialização da política e das relações sociais no Brasil. Rio de Janeiro, Revan, 1999.

WERNECK VIANNA, Luiz; BURGOS, Marcelo Baumann. Revolução processual do direito e democracia progressiva. In: WERNECK VIANNA, Luiz (Coord.). A democracia e os três Poderes no Brasil. Belo Horizonte: UFMG, Rio de Janeiro: IUPERJ/FAPERJ, 2002.

WOLKMER, Antonio Carlos; RONCHI, M. Processos constituintes Latino-Americanos e a presença dos movimentos sociais no Brasil e na Bolívia. In: Revista Culturas Jurídicas, Niterói, RJ, v. 3, n 6, p. 151-171, 2017. ISSN 2359-5744, Disponível em:

http://www.culturasjuridicas.uff.br/index.php/rcj/article/view/187 doi: http://dx.doi.org/10.22409/rcj.v3i6.187. Acesso em: 27 maio 2018.

ZAVASCKI. Teori Albino. Processo coletivo: tutela de direitos coletivos e tutela coletiva de direitos. 3. ed. São Paulo: Revista dos Tribunais, 2008. 


\section{COMO FAZER REFERÊNCIA AO ARTIGO (ABNT):}

CATHARINA, Alexandre de Castro. As dimensões democratizantes do CPC/2015 e seus impactos na cultura jurídica processual estabelecida. Revista Eletrônica do Curso de Direito da UFSM, Santa Maria, RS, v. 14, n. 2, e32849, maio./ago. 2019. ISSN 1981-3694. DOI: http://dx.doi.org/10.5902/1981369432849. Disponível em: https: //periodicos.ufsm.br/revistadireito/article/view/32849 Acesso em: dia mês. ano.

Direitos autorais 2019 Revista Eletrônica do Curso de Direito da UFSM

Editores responsáveis: Rafael Santos de Oliveira e Angela Araujo da Silveira Espindola

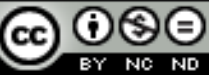

Esta obra está licenciada com uma Licença Creative Commons Atribuição-NãoComercial-SemDerivações 4.0 Internacional.

\section{SOBRE O AUTOR}

\section{AleXANDRE de CASTRo CATHARINA}

Possui graduação em Ciências Sociais pela Universidade Federal do Rio de Janeiro (2003) e graduação em Direito pelo Centro Universitário Augusto Motta (2000). Especialista em Direito Processual Civil e Mestre em Ciências Jurídicas e Sociais pela Universidade Federal Fluminense (2007). Doutor em Sociologia pelo IUPERJ, com ênfase nos Movimentos sociais e a construção dos precedentes judiciais no Brasil. Atualmente atua como Advogado e professor de Direito Processual Civil no âmbito da graduação e da pós-graduação. Tem experiência na área de Direito Processual Civil e em Sociologia do Direito, com ênfase em acesso à justiça, atuando principalmente nos seguintes temas: cidadania, acesso à justiça, direitos coletivos e difusos, tutelas de urgências, direito processual coletivo, precedentes judiciais e teoria da decisão judicial. Membro efetivo do Instituto Brasileiro de Direito Processual (2011). Membro Efetivo do Instituto dos Advogados Brasileiros (IAB). Membro da Comissão de Direito Processual Civil do Instituto dos Advogados Brasileiros. Coordenador do Curso de Direito do Campus Via Brasil, UNESA/RJ (2012/2014). Coordenador do Curso de Direito do Campus Duque de Caxias (2014/2015). Coordenador do Curso de Direito do Campus Nova América, UNESA/ RJ (2015). Coordenador do Grupo de Pesquisa Sociedade Civil, Movimentos Sociais, Cultura Jurídica Processual e Democratização do Processo Civil Brasileiro da Universidade Estácio de Sá UNESA / Campus Nova América, RJ. Pesquisador Produtividade da UNESA (2019). 